\title{
What turns cities into international financial centres? Analysis of cross-border investment banking 2000-2014
}

\author{
DARIUSZ WÓJCIK*, ERIC KNIGHT**, VLADIMÍR PAŽITKA* \\ *School of Geography and the Environment, Oxford University, South Parks Road, OX1 3QY, Oxford, UK, \\ dariusz.wojcik@spc.ox.ac.uk, vladimir.pazitka@ouce.ox.ac.uk \\ **University of Sydney Business School, H70 Abercrombie Building, Room 4180, NSW 2006 Australia, \\ eric.knight@sydney.edu.au
}

\begin{abstract}
Globalisation, financialisation and technology have fuelled competition among international financial centres, with investment banks playing an important part in the process. This study introduces novel data on cross-border investment banking revenues in 2000-14 by city, and investigates their determinants. It shows that international financial centres emerge from cities that are already leading domestic financial centres, with large, deep, flexible and open labour markets, and a large and internationalised non-financial sector, in countries with strong rule of law and contract enforcement. Stock market returns, corporate and finance-specific taxation, English as the official language, and legal family of origin do not seem to matter.
\end{abstract}

Keywords: international financial centres, investment banking, labour market, institutions, taxation

JEL classification: F30, F60, F65, G24, R30

\section{Acknoweldgements}

This project has been funded by the Centre for International Finance and Regulation in Sydney (CIFR F001) and the Hong Kong Research Grants Council (T31-717/12/R). Dariusz Wójcik has also received funding for this project from the European 
Research Council (ERC) under the European Union's Horizon 2020 research and innovation programme (grant agreement No. 681337). Authors are grateful to organisers and audiences of seminars where the paper was presented, including CIFR, KPMG New South Wales, Committee for Sydney, University of Nottingham, Trinity College Dublin, and the Fourth Global conference on Economic Geography, Oxford. Special thanks for comments and support go to David Gallagher, Tim Williams and Martin Sokol. 


\section{Introduction}

The growth of financial and business services is one of the key economic trends of the last thirty years (Daniels, 1993; Desmarchelier, Djellal and Gallouj, 2013). Within the sector, financial firms tend to be larger than other business services firms including those in law, accountancy, marketing, business or human resources consulting. The rise of financial and business services has thus unleashed a race among cities for the status of international financial centres (IFCs), understood as concentrations of firms in the sector that are engaged in cross-border business. This competition can be found in all parts of the world, in advanced, emerging, and developing economies alike. While the US subprime and the Eurozone crises may have tempered such ambitions in some places, in others the crisis is seen as an opportunity to gain market share from leading, established global centres such as London and New York.

IFCs remain icons of modern capitalism and centres of power, and their history is richly documented (Kindleberger, 1974; Cassis, 2010). The literature explains why technology facilitating financial transactions at a distance allows financial firms to operate out of ever fewer headquarter locations, consequently sustaining or even increasing the spatial concentration in the financial sector (Sassen, 2001; Krugman, 1991). However, there is relatively little literature on what turns cities into IFCs. Why is it, for example, that London is Europe's financial capital and not Paris? What are the chances of Shanghai becoming a global financial centre?

The paucity of research on the development of IFCs (beyond descriptive history and case studies) is partly to blame on bias towards manufacturing in much economics and economic geography research, which treats the question of location in the services sector as trivial. Indeed, the term financial centre hardly features in 
economics literature, despite it being a self-evident preoccupation of financial firms as well as local policy makers. This bias is compounded by empirical issues. Data on financial activities is available mostly at the country and firm level. As a result, research on financial centres resorts to proxies such as the size of a stock exchange, employment in financial services, counts of financial firms present or headquartered in cities, or indices of financial centre competitiveness, and tends to focus on success stories, neglecting the more analytical question of why most cities never become IFCs (Kayral and Karan, 2012).

In an effort to address these limitations, this paper analyses a novel dataset based on the combination of capital market data from Dealogic and city-level data from Oxford Economics. This is supplemented with information from Bureau van Dijk's ORBIS and Bankscope, as well as corporate websites. Covering the period of 200014, this dataset allows us to estimate the gross fee revenues from nearly 600 thousand capital market transactions (equity, debt, syndicated loans, and M\&As) worldwide, identify fees from cross-border deals, and assign these to cities hosting the operational headquarters of subsidiary of the principal financial advisor that conducted the transaction. In doing so, we develop a new measure of cross-border investment banking activity, based on the actual business transacted in cities. While this offers only a partial view on IFC activity, the focus on investment banks is justified by a growing body of literature, which demonstrates that they are important movers and shakers of international finance and one of the keystone species inhabiting IFCs (Wójcik, 2012). Strange characterised investment banks as croupiers in the casino of the world economy (1986), and their contribution to the global financial crisis has been well-documented(French et al., 2009) 
We subject data on gross cross-border fees for a sample of 150 cities worldwide and over forty explanatory variables to correlated-random-effects quantile regression and extreme bounds analysis. The findings show that cross-border investment banking activity is influenced by city size, institutional environment, labour market flexibility, and the concentration of financial advisors. Specifically, a city needs size to offer a large and deep labour market necessary for the financial sector. This market has to be flexible to allow easy hiring and firing by what is a notoriously cyclical and unstable industry. Institutions such as rule of law matter, and it is almost impossible to become a top IFC without an effective and efficient enforcement of contracts. It is an advantage for a city to host large global financial firms rather than a myriad of small ones, but a very high concentration of advisors in a city becomes a disadvantage. EU membership seems to enhance the ability of cities to attract deals. Investment banking also tends to flourish in cities that host many headquarters of large nonfinancial companies, particularly if those are active internationally. We also demonstrate that the status of the largest domestic financial centre strongly determines the ability of a city to attract cross-border deals.

Factors that do not seem to affect cross-border investment banking at city level include stock market returns, corporate and financial taxes, whether a city is the political capital of a country, location close to the GMT time zone or whether English is the official language. Overall, we conclude that the development of investment banking centres, an important subset of broader IFC development, is a complex phenomenon, subject to a wide range of factors operating at both country- and citylevel. There seem to be no quick fixes whereby an IFC could be built on the basis of rising stock market valuations or low taxes. Instead, IFCs rise through a slow and 
long process of economic and institutional development. Cross-border investment banking is a game played predominantly by large cities that already enjoy the status of top financial centres within their domestic economies. To succeed cities also need a large and internationally active non-financial corporate sector.

\section{The development of international financial centres}

We first outline a number of factors that have been identified in economic geography and financial geography to account for the relationship between cross-border financial activity and cities. We contextualize our hypotheses using insights from hundreds of interviews we have conducted over the last decade with experts in financial firms and related organisations worldwide. The resulting classification, presented in table 1 , is broad brushed. This is intentional, since our dataset offers a unique opportunity to test a large number of factors potentially affecting IFC development.

$<$ insert table 1 here >

Existing studies suggest that financial development requires political and legal foundations. Political instability and corruption destroy trust necessary for the functioning of a financial market (Rajan and Zingales, 2003). As financial transactions involve claims to private property, it is hard to imagine a financial market without strict protection of property rights (Beck, Demirguc-Kunt and Levine, 2003). Rule of law and judicial independence is therefore needed to protect the parties to financial transactions from arbitrary decisions of governments. At the intersection of law and politics, flexible and predictable financial regulation can enhance and safeguard the quality of the financial system. As financial contracts can be very complex, with many contingent outcomes, and can cover long periods of time, the effectiveness and efficiency with which they can be enforced is particularly important 
(Chinn and Ito, 2006). To allow credit and equity transactions to flourish, law also needs to offer protection for creditors and shareholders alike (Clark and Wójcik, 2007). These protections are said to be embedded in the English common law more than in other legal systems (La Porta et al., 1997, 1998).

While political and legal factors typically apply to whole countries, there is also a potentially significant political and legal factor specific to cities. If a city hosts central political, regulatory and legal institutions of a country, it may offer advantages to international financial firms, for example, better access to information about laws and regulations relevant to finance (Lai, 2012). IFCs are mostly capital cities, and exceptions to this rule may look less exceptional on closer scrutiny. New York, for example, hosts the most influential part of the country's central bank - the Federal Reserve Bank of New York.

IFCs need highly educated and qualified labour in a large, deep, flexible and open labour market (Ellison, Glaeser and Kerr, 2010). Investment banking in particular is a highly cyclical industry. Openness makes the supply of labour more flexible, but also provides expertise in foreign markets, particularly important for internationally active firms (Beaverstock and Smith, 1996). As English is the international language of finance, we might expect cities where English is the main language to enjoy an advantage (Stulz and Williamson, 2003). ${ }^{1}$

\footnotetext{
${ }^{1}$ While the size of the labour market and language are factors that operate primarily at the city level, and flexibility and openness are decided by national laws and policies, quality of education may matter at both the city and country level. After all the best educated graduates in a country should be attracted to jobs in an IFC even if they come from outside the city.
} 
Cross-border financial deals require a lot of face-to-face and long-distance interactions, which complement each other (Gaspar and Glaeser, 1998). Consequently, infrastructure that facilitates mobility of people and information, within and between cities, including high-speed Internet, intra- and inter-urban transport networks and airports, is necessary for an IFC (Warf, 1989). While high-quality office space is also a basic necessity, its supply may be expected to adjust to demand so quickly that it should not be considered a significant factor that affects the development of IFCs.

The next two groups of factors concern the development of the corporate sector, the major source of demand for cross-border financial deals. While services rendered in a financial centre to domestic firms represent domestic, not international finance, a large domestic corporate sector, and particularly the presence of large domestic companies, increases the potential for cross-border M\&As. Foreign firms interested in M\&As in a country often hire advisors operating in that country (Very and Schweiger, 2001). This factor may operate at both city and country level. If large domestic or local non-financial companies operate internationally they are more likely to become targets of cross-border M\&As. Generally, IFCs are expected to thrive from economic openness (Rajan and Zingales, 2003; Baltagi, Demetriades and Law, 2009). International trade encourages foreign investment, which can take the form of crossborder M\&As or firms raising capital in foreign markets through syndicated loans, equity and bond issuance. To conduct these activities firms often hire advisors in foreign markets.

Close relationship between international trade and cross-border finance is evident throughout history. Genoa, Venice, Antwerp, Amsterdam, and London built their financial prowess on the back of maritime commerce (Cassis, 2010). New York's 
ascent to the top of the U.S. financial centre hierarchy was helped by the Erie Canal, built in 1825, which connected its seaport with the Great Lakes (Kindleberger, 1974). Merchant banks - specialists in international trade and finance - gave rise to modern investment banks. Arguably, financial transactions related to trade in goods have long been overwhelmed by other types of cross-border financial activity, and airborne trade as well as trade in services have grown faster than the seaborne variety. As a result, access to sea and the presence of a large seaport may no longer matter to IFCs in the $21^{\text {st }}$ century.

Since we measure international financial centre activity with gross fees from cross-border capital market transactions (equity, debt, syndicated loans, and M\&As), we are able to investigate a number of factors related to financial sector development, as long as they do not encompass the activity we are trying to explain. The first candidate is the domestic financial activity. It is hard to think of any country, where the leading IFC is not the top domestic financial centre. Large financial firms have no reason to specialise in foreign transactions only; they serve both domestic and foreign clients. In evolutionary terms, many firms gain expertise and market shares in domestic finance before they develop international activities (Morrison and Wilhelm, 2008). Both reasons should lead to a coincidence of international and domestic financial centre activity.

IFCs are often associated with stock exchanges. With virtualisation of trading, exchanges no longer serve as key meeting points of traders, and thus their location should matter less than in the old days of physical trading floors (Engelen and Grote, 2009). However, when a foreign company wants to raise capital through the Hong Kong Exchanges, for example, it is still likely to seek advisors in Hong Kong, who 
have established relationships with the local exchange. Considered in relation to the size of the domestic economy, the size of the stock market may reflect the popularity of securities in the domestic economy, which may not only attract foreign issuers, but also enhance domestic and local expertise and environment conducive to the development of internationally active securities industry (Wójcik, 2011). The level of stock prices may also matter for cross-border financial activity, since bull markets attract equity issues, both domestic and foreign (Sarkissian and Schill, 2004). On the other hand, low valuations may attract M\&As by foreign firms (Erel, Liao and Weisbach, 2012). Both equity issues and M\&As may raise demand for local financial advisors.

Institutional investors focus on buying securities on behalf of their beneficiaries, while investment banks focus on selling them on behalf of their issuers. The two sides of the securities industry work closely with each other, and issuing companies often reach institutional investors through investment banks that have close relationships with institutional investors (Morrison and Wilhelm, 2008). For that reason, we may expect the presence of large institutional investors, at both country and city level, to be conducive to the development of an IFC.

Investment banking market structure may be of consequence to IFC development. A single provider of capital market services in a city would have a monopoly power on all firms that need a service provider in this city. Lack of competition could deter customers, and limit incentives for innovation. We therefore expect competition in investment banking to be beneficial to the development of an IFC.

As a final factor within financial sector development, we consider large government debt, measured in relation to GDP, as a burden to the attractiveness of a 
country's IFCs. Large government debt may crowd out private equity or corporate bond issuance, and raise the perceived risk of a financial crisis, deterring foreign firms from using the services of the country's financial sector.

We expect a negative impact of high taxes on the development of IFCs, particularly with regard to personal taxes. Corporate taxes and taxes specific to financial transactions, such as interest or dividend tax, can be more easily avoided through incorporation and booking assets in low-tax jurisdictions (Haberly and Wójcik, 2015). In addition to taxation, general macroeconomic conditions such as high real interest rates and high inflation may dampen international financial activity. High real interest rates imply a high cost of capital, while inflation distorts financial decision-making and adversely affects financial development in general. Quantitative easing, common since 2008, could have a negative influence on investment banking by dampening real interest rates.

Much has been written about the advantages enjoyed by London as the financial centre located on the prime meridian (Clark and Thrift, 2005). Proximity to the GMT zone increases the daytime overlap of an office with offices in Americas and Asia. This is particularly relevant in international finance, where up-to-date information from around the world is critical to pricing assets and executing deals. On the other side of the spectrum from physical geography lies the general quality of life in a city. Finance professionals, particularly those who work on international deals, are highearners expecting a high standard of living. They are mobile and likely to take quality of life into account when choosing their place of work (Florida, 2002).

Our classification of major factors expected to influence the development of IFCs, and centres of international investment banking in particular, offers a number of 
contributions. In contrast to literature on financial development in economics, which is devoted entirely to countries as units of analysis, we pay equal attention to city- and country-level factors. Second, it allows us to test relationships between finance and the 'real economy', including the development of the non-financial corporate sector. This helps us address the issue of financialisation (Hall, 2012; French, Leyshon and Wainwright, 2011; Engelen, 2008). Finally, the list , although broad brushed, tries to capture the complex, multi-faceted nature of IFCs, affected by politics, law, culture and geography in addition to economic forces.

\section{Data \& Methodology}

Since we focus on on the development of IFCs, we developed a database that could provide data aggregated at city level. To this end we use proprietary data from Dealogic, which offers comprehensive coverage of investment banking deals across equity capital markets (ECM), debt capital markets (DCM), syndicated loans (Loans) and mergers and acquisitions (M\&As) across the world. Totalling 593,462 deals across the four groups of products for the period between the start of 2000 and the end of 2014, our sample offers a robust record of capital market activity worldwide.

All types of capital markets services providers are captured, including bulgebracket investment banks like Goldman Sachs or Morgan Stanley, universal banks providing capital market services, like Deutsche Bank, , investment banking boutiques like Rothschild\&Co, and consulting companies like $\mathrm{PwC}$ offering investment banking services. To be sure, the four groups of deals covered focus on relationship-based investment banking, excluding revenues from trading, securitisation of loans or shadow banking activities. While we are unaware of any 
source that would offer such information in a form attributable to cities rather than whole companies, we recognise this as a limitation of our analysis.

Dealogic data provides names of financial advisors at subsidiary level. We used those names to identify the location of the operational headquarters of the top 500 financial advisors for every product-year combination ${ }^{2}$ by searching through Orbis database, Bankscope and company websites. Each deal is assigned to the city where the principal advisor has operational headquarters ${ }^{3}$. Cities are defined as metropolitan areas, in accordance with the conventions used by Oxford Economics - Global Cities database. By focusing on operational headquarters we limit our ability to consider the offshore finance element of investment banking activity. Assigning subsidiaries to their place of incorporation would allow a focus on offshore finance, but then we would lose sight of places where transactions concerned actually took place.

As a measure of activity we use the gross fee revenue, which is additive across products, unlike deal values which are not directly comparable due to large variation of fee margins across products. Gross fee revenue shows how much firms based in a city actually earn from capital market transactions. Using operational headquarters at subsidiary level is vital, allowing us to escape the trap reproduced in existing research of allocating financial activity to the headquarters of the parent company. While for approx. 20\% deals, data on fees was available from Dealogic, for other deals gross

\footnotetext{
${ }^{2}$ This process has led to a list of 7165 unique names of financial advisors.

${ }^{3}$ In the event that there were multiple principal advisors involved in the deal, the deal has been apportioned among them based on the available breakdown in Dealogic data and subsequently a single deal has been often apportioned to multiple cities based on the shares of the underlying advisors.
} 
fees were estimated using a model based on available fee data ${ }^{4}$. In order to adjust gross fees for inflation, we have used a GDP deflator derived from Oxford Economics - Global Cities database, thus normalizing all of the aggregate gross fees to constant 2012 USD.

As we study IFCs, we have focused on cross-border deals, defined as those in which a financial advisor works for a client of a different nationality than their own. Nationality of both the advisor's subsidiary and the client have been defined based on the country of their operational headquarters ${ }^{5}$. This simple definition is used for clarity. The exclusion of domestic deals from our measure of IFC activity is justfied by our focus on international finance and competitiveness of IFCs. It also allows us to analyse international as a function of domestic activity. Combining domestic with cross-border fees in the dependent variable would overcomplicate the analysis.

To investigate factors that turn cities into centres of investment banking, we need a sample including cities that have no IFC activity. We have used a sample of 150 cities with the highest average employment in financial and business services (FABS) over the period 2000-14, according to Oxford Economics - Global Cities Database. This allowed us to build a panel dataset with 2,250 city/year observations. Approximately $50 \%$ of the observations of our dependant variable equal 0 , which represents a significant degree of censoring. Given that our dependent variable is bound by a natural non-negativity condition, we are effectively facing a scenario similar to that of

\footnotetext{
${ }^{4}$ Fees as percentage of deal value for each group were modelled as a function of transaction size, industry and location of the client, other specific deal characteristics, as well as a full set of time period fixed effects. The models have then been used to predict percentage fees for deals that had missing data on fees. Finally, percentage fees were multiplied by deal values to arrive at the value of fees.

${ }^{5}$ Transactions between Hong Kong and Mainland China are also treated as cross-border.
} 
Tobin (1956). As we do not have any prior knowledge about the form of the distribution of residuals in our model, and keeping in mind the reliance of maximum likelihood estimator (MLE) for Tobit models on the correct parametric specification of the error term distribution (Arabmazar and Schmidt, 1982), we have followed the avenue of semiparametric estimators for conditional quantiles in contrast to the more conventional conditional mean estimators.

Within the quantile regression (QR) framework we have used a specification of correlated-random-effects quantile regression (CREQR) estimator for panel data proposed by Bache et al. (2013), which extends anestimator proposed by Abrevaya and Dahl (2008) to unbalanced panels. This has allowed us to break the correlation between regressors and time constant unobserved heterogeneity by including correlated random effects (CRE) terms in the regression equation for time-varying explanatory variables, thus correcting for the potential bias in our coefficient estimates caused by reversed causation from the dependent variable. Given the presence of missing values in some of our explanatory variables, the method proposed by Bache et al. (2013) allows us to construct CRE terms even for an unbalanced panel dataset and thus is directly applicable simply by using averages of explanatory variables calculated for each city across the available time periods as covariates in the model along with the original variables ${ }^{6}$. This then gives the estimated coefficients on variables treated in this way a counterfactual interpretation, so they can be seen as causal effects rather than just partial correlations, as they would have been with the

\footnotetext{
${ }^{6}$ This approach is only feasible for time varying variables and therefore only such variables can have CRE terms constructed for them in order to account for potential correlation between regressors and time constant unobserved heterogeneity. Time constant variables can still be included in the model, however, without the respective CRE terms.
} 
application of standard cross-sectional QR. This estimator is available as part of the rqpd package in $\mathrm{R}$ and uses generalised bootstrap standard errors proposed by Bose and Chatterjee (2003) with unit exponential weights, which recognize the panel structure of our dataset and are estimated based on random draws of cross-sections rather than individual observations, thus accounting for the dependece between individual observations for the same cross-section.

The lack of an integrated theory of IFC development implies model uncertainty, and thus we have subjected our coefficient estimates to extreme bounds analysis (EBA) similar to that of Sala-i-Martin (1997) by estimating a series of models with varying sets of explanatory variables using the ExtremeBounds package in $\mathrm{R}$ developed by Hlavac (2014). An explanatory variable is deemed to be robustly related to the dependent variable, if sufficiently large $^{7}$ part the cumulative distribution function (CDF) of its coefficient estimates compiled from a large number of estimated models with varying functional forms lies on the same side of zero.

To test the factors of IFC development summarised in table 1, we represent them with over forty variables. Definitions and sources are presented in table A1 in the appendix, descriptive statistics in table A2. Table 2 shows the top 25 international financial centres for the 2000 - 2014 period by gross fees earned from cross-border transactions, and includes 14 cities in Europe, 6 in North America and 5 in AsiaPacific.If domestic deals were included, the table would be dominated by US cities,

\footnotetext{
${ }^{7}$ We selected $90 \%$ of CDF as the cut off point for robustness tests of coefficient estimates and therefore if $90 \%$ or more of the CDF of coefficient estimates is on the correct side of zero, we treat such variable as being robustly related to the dependent variable provided that it is statistically significant at conventional levels.
} 
operating in by far the biggest domestic market for capital market services in the world (Wójcik et al., 2016). The preponderance of European cities is partly due to the intensification of cross-border capital market activity in the wake of European financial integration and the introduction of Euro (Allen and Song, 2005).

$<$ insert table 2 here $>$

\section{Results and analysis}

Table 3 presents our key findings from a parsimonious model, including only a subset of explanatory variables, whichwere selected through EBA with a view to maintain a manageable number of regressors in order to keep the standard errors of our estimates low and allow for statistically significant relationships in the data to be uncovered. For the purpose of economic interpretation we will focus on quantifying the effects of explanatory variables on the $99.9^{\text {th }}$ conditional percentile of the distribution of natural logarithm of the cross-border fees earned at a city level. Consequently, our main results should be interpreted as referring to the effects of explanatory variables on the upper bound of IFC activity rather than its average level. We will discuss results, analyse and subject them to robustness tests in the order of factors introduced in table 1.

$<$ insert table 3 here $>$

\subsection{Political and legal institutions}

To address multicollinearity concerns for five measures of institutional environment, we have conducted an EBA (figure 1; details in table A3). The cost of contract enforcement was included in all models estimated and has been found to be robustly linked to cross-border fees, regardless of whether rule of law, regulatory quality, 
control of corruption or political stability are included or not. Histograms in figure 1 indicate that the estimates on all four of the proxies for institutional quality are overwhelmingly positive across the models. However, more detailed results in table A3 indicate that only rule of law is consistently statistically significant in all of the estimated models and all of its coefficient estimates are positive as expected. Hence, rule of law is included in the parsimonious model alongside contract enforcement. We should stress however, that although the impact of political stability, control of corruption and regulatory quality are difficult to isolate, it does not mean they have no positive influence on IFC development.

< insert figure 1 here >

An estimated $30.3 \%$ increase in the $99.9^{\text {th }}$ percentile of cross-border fees is associated with a mere $1 \%$ reduction in the cost of contract enforcement measured as a percentage of claim. As shown in figure 2 this effect is most pronounced in the right tail of the conditional distribution and lacks statistical significance at the lower conditional quantiles of cross-border fees. In contrast, rule of law remains positive and statistically significant across all of the conditional quantiles examined here $\left(75^{\text {th }}\right.$ percentile $-99.9^{\text {th }}$ percentile), with causal effect estimated at $9.22 \%$ increase in the $99.9^{\text {th }}$ conditional percentile of cross-border fees for every percentile increase in ranking by rule of law ${ }^{8}$ (table 3). The speed of adjustment in the case of both rule of law and cost of enforcement of contracts has been estimated as 1 year, given that

\footnotetext{
${ }^{8}$ In order to derive unbiased estimates of causal effects of rule of law and the cost of contract enforcement, it has been necessary to break the link between these regressors and the time constant unobserved heterogeneity, which in this case would have biased both coefficient estimates in the opposite direction to their causal effects and subsequently would have led to a substantial understatement of their economic significance.
} 
contemporary terms become insignificant in the presence of lagged values ${ }^{9}$. In other words, institutional changes need to take root before they can attract international financial activity.

$$
<\text { insert figure } 2 \text { here }>
$$

Figure 3 and table A4 present evidence from an EBA testing the sensitivity of coefficient estimates on the rule of law and the cost of contract enforcement to the inclusion of additional variables on top of those included in the parsimonious model presented in table 3. Both of them are robustly related to cross-border fees and the kernel density of the coefficient estimates suggests that these coefficient estimates are not distributed normally across the 254 models estimated. Without making any assumptions about the distribution of the coefficient estimates across the estimated models, we can observe that the majority of the cumulative density function (CDF) of coefficient estimates on cost of contract enforcement (94.54\% of CDF) and rule of law rank (99.98\% of CDF) is on the expected side of the zero, implying that these estimated effects are robust to a wide range of specifications of the functional form of our model, assuming that the key control variables are included.

$$
<\text { insert figure } 3 \text { here }>
$$

While the analysis conducted here makes a compelling case for the statistical association between institutions such as rule of law, contract enforcement and the development of cities as investment banking centres, it does not preclude a possibility that this is a two-way relationship. Investment banks, through lobbying and other

\footnotetext{
${ }^{9}$ Higher order lagged values were considered, but a first lag has been found to be sufficient to capture the dynamics of both variables.
} 
activities, can influence the political and legal institutions of their host countries and cities.

Contrary to expectations, we have not found any statistically significant impact of the protection of property, creditor or shareholder rights on cross-border fees. As was the case with political stability, control of corruption and quality of regulation, this does not necessarily imply they are entirely irrelevant to IFC development. Rather, the relationship between institutional environment and the IFC activity is best captured by the rule of law variable. Results presented in table A4 demonstrate that when we control for rule of law in every model that has been estimated as part of the EBA routine, the link between English.Common.Law and cross-border fees observed in table A3, where rule of law was controlled for only in one quarter of the estimated models, breaks down. In other words, the variation in cross-border fees among countries of different legal traditions can be explained by the current state of rule of law in these countries. The legal tradition on its own does not seem to matter to IFC development. Finally, the results suggest that the status of the political capital of a country provides no significant advantage to IFCs.

\subsection{Labour market}

Most political capitals are also the largest cities of their countries, with largest internal markets, and the latter may be more important than political capital institutions per se in facilitating IFC activity. Results support this proposition and help explain why we find no significance for the political capital status. The size of a city's population has proven to be an important determinant of IFC activity, with an estimated $5.80 \%$ increase in the $99.9^{\text {th }}$ conditional percentile of cross-border fees for 
every $1 \%$ increase in the population of a city. This effect is obviously conditional on other regressors, and so only large cities in countries with the right conditions, including low cost of contract enforcement and strong rule of law, are likely to benefit from population size.

While population may be used as a proxy for the size of the labour market, the presence of top universities may indicate the quality of labour supply available to financial firms. We have found that countries with a larger base of highly ranked universities host larger IFCs. There is an estimated $4.10 \%$ increase in the $99.9^{\text {th }}$ percentile of cross-border fees earned for every university ranked in the top 500 worldwide. In contrast, we found no evidence that the presence of top universities matters at the city level, which seems consistent with the observation that IFCs draw graduates from top universities at least across a whole country. Although the coefficients estimate on the top 500 university variables may be slightly biased due to these variables being time constant and consequently making it impossible for us to construct the CRE terms, there is a strong case to be made here for causality, given that financial services (especially so investment banking) are a highly knowledge intensive sector, requiring top talent, expertise and technical skills, which are very difficult to develop in an environment without strong universities.

With respect to labour market flexibility, we have estimated a significant reduction of $-12.68 \%$ at the $99.9^{\text {th }}$ conditional percentile of cross-border fees for every additional week of statutory redundancy pay. EU membership has an estimated effect of $587 \%$ on cross-border fees, indicating very large gains for IFCs operating within an integrated market for labour and financial services. The fact that we already control for time-zone effects, and studies that show an increase in cross-border 
investment banking activity in the wake of European financial integration and the introduction of Euro, reasure us in the significance of this result (Allen and Song, 2005).

Given the large overlap between the incidence of the English language and the English common law, these variables had to be treated separately. Results show that English as the official language in a country does not relate significantly to crossborder fees when we control for rule of law, but does when we do not control for it in the majority of estimated models as shown in table A3. The use of English in international finance is a fact, and so it appears that location in a country without English as the official language does not really constrain the supply of English speakers to IFCs.

\subsection{Infrastructure and non-financial sector development}

Infrastructure measured with LN.Secure.Net.Servers and LN.Metro.Stations is not robustly related to cross-border fees and does not offer any additional explanatory power when added to the parsimonious model (table 3). Either our variables do not adequately capture the quality of infrastructure or it is indeed largely irrelevant. Of course, it must matter for IFC development that Singapore has a better infrastructure than Jakarta. However, once we control for political and legal institutions, which conspire against Jakarta, the significance of infrastructure may fade away.

Presence of large non-financial companies (HQ.10bn.Count.City), both public and private, has yielded an overwhelmingly positive coefficient estimate, implying $0.8 \%$ increase in cross-border fees for every large non-financial company located in the given city, and with $87.5 \%$ of statistically significant coefficient estimates at 
conventional levels (table A3). At the same time, presence of large non-financial companies at national level (HQ.10bn.Count.Country) has yielded a negative mean coefficient (table A3). While the result at city level is consistent with our hypothesis, that at country level contradicts it. After all a large pool of domestic companies should increase the likelihood of foreign companies hiring advisors in that country to advise on M\&As. One possibility is that a large domestic customer base focuses advisers on domestic at the expense of cross-border business.

Internationalization of companies from a given country (Foreign.Sales.Pct) has been estimated to increase the conditional $99.9^{\text {th }}$ percentile of cross-border fees by $3.41 \%$ for every percentage point increase. Once we control for this impact, economic openness (Exp.Imp.Pct.GDP) does not offer any additional value (table A3).

There is a $-0.91 \%$ estimated reduction in cross-border fees for $10 \%$ increase in seaport traffic, suggests that the link between world maritime transport and international finance is indeed a matter of history of little relevance in the $21^{\text {st }}$ century.

\subsection{Financial sector development}

The hypothesis that IFCs develop in cities that lead the domestic financial sector in their countries finds strong support. The top domestic financial centres ${ }^{10}$ have $236 \%$ higher level of gross fees at the $99.9^{\text {th }}$ conditional percentile than other cities. The functional form of our models implies that the leading financial centre will also benefit proportionately more from improvements in other determinants of cross-

\footnotetext{
${ }^{10}$ The leading domestic financial centre is identified simply as the city with the highest level of gross fees earned from domestic deals (deals for which the nationality of operations of the financial advisor and the client is the same).
} 
border fees such as rule of law contract enforcement than other cities in the same country.

In contrast to our initial hypothesis that the association between IFCs and stock exchanges may be little more than a historical artefact, the co-location of stock exchanges and investment banking centres holds very well. There is a $496 \%$ difference in the $99.9^{\text {th }}$ conditional percentile of cross-border fees between cities that have a stock exchange and those that do not. Causality cannot be easily established here, but it cannot be ruled out either. It is possible that stock exchanges still serve as symbols of their financial centres, enhancing their reputation and attracting international financial advisors.

Stock market development, measured by total value of publicly listed companies as a percentage of GDP (Stocks.Tot.Val.Pct.GDP) has not been found to provide any significant explanatory power in (table A5). The same applies to stock market returns. It is possible that the potentially positive impact of high valuations attracting equity offerings, and the negative impact of high valuations deterring foreign corporate acquirers, cancel each other out.

Does the presence of large domestic or local asset managers stimulate the IFC activity? Given that the data available only includes a part of the time period considered in this study ${ }^{11}$, we have estimated a separate set of models for these variables. We find evidence of co-location of asset managers and financial advisors at city level (table A6), however, the link between time-constant unobserved heterogeneity at city level and assets under management is not controlled for, and

${ }^{11}$ TW data on top 500 asset managers used here is limited to 2006, 2007, 2009, 2010, 2011 and 2012 time periods. 
thus the significant partial correlation may not necessarily represent a causal relationship. Once the CRE term for assets under management at city level has been included in the equation to control for this potential source of endogeneity, the relationship breaks down as indicated in table A7. This implies that although financial advisors and asset managers co-locate in the same cities, increasing the amount of assets managed in a particular city would not cause an increase in the cross-border fees earned by financial advisors. Instead it seems that asset managers are drawn to the same characteristics that make cities attractive to financial advisors.

Concentration in the financial advisory market at city level, measured by Herfindahl index based on market shares of financial advisors in the city, has been found to have an effect that varies across the distribution of the variable and approximates an inverse U shape (figure 4). Cross-border fees tend to grow with increasing concentration of advisors up to their peak at the level of Herfindahl index of 0.54 (representing a duopolistic market structure), but fall when concentration grows beyond this point. More specifically, increase in the Herfindahl index from 0.1 to 0.54 is associated with a $112.95 \%$ increase in cross-border fees, while increase from 0.54 to 0.8 (a nearly monopolistic market structure) would lead to an estimated fall of cross-border fees by $24 \%$. Thus, instead of seeing straightforward benefits from competition, we see the tradeoff between economies of scale associated with higher levels of concetration and damage to the competitive environment caused by a local monopoly or near-monopoly. EBA analysis confirms the robustness of this result.

$<$ insert figure 4 here $>$ 
Level of government debt as a percentage of GDP has not displayed a statistically significant relationship with cross-border fees (table A4).

\subsection{Taxation, macroeconomic and other factors}

In the wake of the global financial crisis, large international banks often used threats that they will leave a financial centre should the tax burden rise. The evidence on the role of taxes is mixed. The top margin of personal income tax and social security contributions (Pers.Inc.Tax.Soc.Sec) has been found to be negatively related to crossborder fees with an estimated reduction of $-4.11 \%$ in cross-border fees for every percentage point increase (table A3). On the other hand, low corporate profit tax (Corp.Tax), interest tax (Interest.Tax) or dividends tax (Dividends.Tax) seem to provide no competitive advantage to IFCs defined as headquarters of capital market operations, rather than mere booking centres. This supports our observation that corporate and financial transaction taxes may be more readily avoidable through the use of offshore jurisdictions than personal taxes or social security contributions.

Real interest rates and inflation appear to harm IFCs, as expected, specifically by reducing cross-border fees by $-8.99 \%$ and $-8.02 \%$ per one percentage point rate increase respectively. Contrary to much literature, proximity to the GMT time zone does not appear to provide any systematic advantage once all other factors are controlled for.

Quality of life in a city measured by the Spatially Adjusted Liveability Index (Spat.Adj.Live.Top.25) has been identified as a factor with substantial economic significance, implying that cities that ranked in the top 25 worldwide have an estimated 265\% higher cross-border fees that those lower down the list. Subject to the 
same caveats as all coefficient estimates on time constant variables, quality of life in a city is likely to play a part in the ability of investment banks to attract top talent.

\section{Conclusions and implications}

This study sought to explain the determinants of IFC development by focusing on cross-border investment banking. Based on literature on financial development, financial history, economic and financial geography, case studies, and interviews, we proposed a new classification of key factors that could be hypothesized to affect IFC development at city or country level. We then apply a correlated-random-effects quantile regression estimator jointly with extreme bounds analysis to a unique dataset on investment banking fees to test these hypotheses and examine which of these factors are statistically and economically significant.

Political and legal institutions, with enforcement of contracts and rule of law in the lead, are crucial for IFCs. Once these are in place, our findings suggest that it does not matter which legal family of origin they belong to. Whether an IFC is the political capital of the country does not appear to be significant either. IFCs need highlyskilled employees from a large, flexible, and open labour market, but whether English is their official language does not appear to influence the supply of labour. IFCs tend to develop in leading domestic financial centres that are not dominated by a single large bank. However, we find that less successful IFCs tend to have highly fragmented markets for investment banking services. The presence of large internationally active non-financial firms also helps IFCs.

The size of the stock market relative to GDP, the level of stock market prices, and corporate and finance-specific taxation (in contrast to personal income taxes) were not found to be significant to IFC development. As such, our findings paint the 
picture of IFC development rooted more in the non-financial economy than often assumed. While tax changes may be important for competition among offshore financial centres based on where transactions are booked, these appear less important with regard to where transactions are actually conducted. The results also indicate that factors important for the emergence of IFCs in the past may have lost significance over time. For example, it appears that London's size as a city and corporate command and control centre is now much more important to its IFC activity than the fact that it is the capital of an English speaking country, with English common law, a seaport, and location in the GMT zone.

We recognize a number of potential limitations associated with our findings. First, we recognize the potential for statistical bias in the estimated coefficients. However, we have outlined a number of steps taken to minimize the methodological pitfalls associated with potential simultaneity between dependent and explanatory variables. Second, existing literature on financialisation demonstrates that the size and mode of financial activity in cities and countries may influence their institutions and policies (French, Leyshon and Wainwright, 2011; French, Leyshon and Thrift, 2009; Engelen, 2008). This suggests that the financial system is likely to co-evolve with urban, national and international economies and polities in complex ways, which escape even sophisticated quantitative analysis. In this respect, we moderate the extent to which our findings show the direction of causality. Nevertheless, we hope that our study will complement more qualitative research on IFC development, including within-case analysis and small-sample comparative case studies that unpack these finer-grained mechanisms in more detail (Engelen and Grote, 2009; Leyshon and Thrift, 1997). Our results on the strong relationship between the financial and non- 
financial sector also underscore the potential for studying the interplay between the Global Production Networks and Global Financial Networks (Coe, Lai and Wójcik, 2014).

Finally, the limitations of the dataset collected for this paper present opportunities for further research. It would be desirable to extend the period of data coverage beyond 15 years to make it correspond better with long-term factors that underpin IFC development. Second, the analysis could be extended to compare factors affecting cross-border activity with those influencing domestic finance. Third, the results based on the location of operational headquarters of financial institutions presented here could be compared with those based on their place of incorporation. Fourth, we hope that in the future it will be possible to obatin data on the complete array of investment banking activities, as well as those in other parts of the financial sector, including commercial banking, insurance, and asset management.

\section{REFERENCES}

Abrevaya, J., Dahl, C.M. (2008) The effects of birth inputs on birthweight: evidence from quantile estimation on panel data. Journal of Business \& Economic Statistics, 26: 379-397.

Arabmazar, A., Schmidt, P. (1982) An investigation of the robustness of the Tobit estimator to non-normality, Econometrica: Journal of the Econometric Society: 1055-1063.

Allen, F. and Song, W.L. (2005) Financial integration and EMU. European Financial Management, 11: 7-24.

Baltagi, B, Demetriades, P. and Law, S.H. (2009) Financial development and openness: evidence from panel data. Journal of Development Economics , 89: 285-296.

Beaverstock, J.V. and Smith, J. (1996) Lending jobs to global cities: Skilled international labour migration, investment banking and the city of London. Urban Studies, 33: 1377-1394. 
Beck, T., Demirguc-Kunt, A., Levine, R. (2003) Law, endowments, and finance. Journal of Financial Economics, 70: 137-181.

Bhetuwal, K.R. (2007) Financial liberalization and financial development in Nepal. Economic Review, 41: 23-41.

Bose, A., and Chatterjee, S. (2003) Generalized bootstrap for estimators of minimizers of convex functions. Journal of Statistical Planning and Inference, 117: 225-239.

Cassis, Y. (2010) Capitals of Capital: The Rise and Fall of International Financial Centres 1780-2009. Cambridge: Cambridge University Press.

Chernozhukov, V. (2005) Extremal quantile regression. Annals of Statistics: 806-839.

Chinn, M. and Ito, H. (2006), What matters for financial development? Capital controls, institutions, and interactions. Journal of Development Economics, 81: 163-192.

Clark, G.L., Thrift, N. (2005) The return of bureaucracy: Managing dispersed knowledge in global finance. In: Knorr Cetina, K., Preda, A. (Eds) The Sociology of Financial Markets. Oxford: Oxford University Press, pp. 229-249.

Clark, G.L. and Wójcik, D (2007) Geography of Finance: Corporate Governance in a Global Marketplace. Oxford: Oxford University Press.

Coe, N., Lai, K.P.Y., Wójcik, D. (2014) Integrating finance into Global Production Networks. Regional Studies, 48, 5: 761-777.

Daniels, P. (1993) Service Industries in the World Economy. Oxford: Blackwell.

Desmarchelier, B., Djellal, F. and Gallouj, F. (2013) Knowledge intensive business services and long term growth. Structural Change and Economic Dynamics, 25: 188-205.

Djankov, S., McLiesh, C., Shleifer, A. (2007) Private credit in 129 countries. Journal of Financial Economics, 84: 299-329.

Ellison, G., Glaeser, E. and Kerr, W. (2010) What causes industry agglomeration? Evidence from coagglomeration patterns. American Economic Review, 100: 1195-1213.

Engelen, E. (2008) The case for financialization. Competition and Change, 12, 2: 111-119. 
Engelen, E. and Grote, M. (2009) Stock exchange virtualization and the decline of second-tier financial centres - the cases of Amsterdam and Frankfurt. Journal of Economic Geography, 9, 5: 679-696.

Erel, I., Liao, R., Weisbach, M. (2012) Determinants of cross-border mergers and acquisitions. Journal of Finance, 67: 1045-82.

Florida, R. (2002) The Rise of the Creative Class. New York: Basic Books.

French, S., Leyshon, A. and Thrift, N. (2009) A very geographical crisis: the making and breaking of the 2007-2008 financial crisis. Cambridge Journal of Regions, Economy and Society 2, 2: 287-302.

French, S., Leyshon, A., Wainwright, T. (2011) Financialzing space, spacing financialization. Progress in Human Geography 35, 6: 798-819.

Freund, C., Weinhold, D. (2002) The internet and international trade in services. American Economic Review, 92: 236-40.

Gaspar, J., Glaeser, E. (1998) Information technology and the future of cities. Journal of Urban Economics, 43: 136-56.

Haberly, D. and Wójcik, D. (2015) Tax havens and the production of offshore FDI: an empirical analysis. Journal of Economic Geography, 15: 75-101.

Hall, S. (2012) Geographies of money and finance II: Financialization and financial subjects. Progress in Human Geography 36, 3: 403-411.

Hlavac, M. (2014) ExtremeBounds: Extreme Bounds Analysis in R. Available at SSRN 2393113.

Holst, S., Bache, M., Dahl, C.M., Kristensen, J.T. (2013) Headlights on tobacco road to low birthweight outcomes. Empirical Economics, 44: 1593.

Kayral, I.E., Karan, M.B. (2012) The research on the distinguishing features of the international financial centres. Journal of Applied Finance \& Banking, 2: 217-38.

Kindleberger, C. (1974) The formation of financial centres: a study in comparative economic history (Princeton Studies in International Finance). Princeton: Princeton University Press. 
Koenker, R., Bassett Jr, G. (1978) Regression quantiles. Econometrica: Journal of the Econometric Society: 33-50.

Koenker, R., and Machado, J.A. (1999) Goodness of fit and related inference processes for quantile regression. Journal of the American Statistical Association, 94 : 1296-1310.

Koenker, R., Portnoy, S., Ng, P.T., Zeileis, A., Grosjean, P. and Ripley, B.D. (2016), Package 'quantreg'.

Koenker, R. (2004), Quantile regression for longitudinal data. Journal of Multivariate Analysis, 91: 74-89.

Krugman, P. (1991), Geography and Trade. Cambridge: MIT Press.

Kuo, L. (2007) China wants to make a Johannesburg suburb into the "New York of Africa”. Quartz, 07 November 2013. Available at http://qz.com/144216/china-wants-to-make-ajohannesburg-suburb-into-the-new-york-of-africa/.

La Porta, R., Lopez-de-Silanes, F., Shleifer, A., Vishny, R. (1998) Law and finance. Journal of Political Economy, 106: 1113-55.

La Porta, R., Lopez-de-Silanes, F., Shleifer, A., Vishny, R. (1997) Legal determinants of external finance. Journal of Finance, 52: 1131-50.

Lai, K. (2012), Differentiated markets: Shanghai, Beijing and Hong Kong in China’s financial centre network. Urban Studies, 49: 1275-96.

Leyshon, A. and Thrift, N. (1997) Money/Space: Geographies of Monetary Transformation. London: Routledge.

Ministry of Finance, Government of India (2007) Making Mumbai and International Financial Centre. Report of the High Powered Expert Committee. Available at http://www.finmin.nic.in/mifc/fullreport/execsummary.pdf.

Morrison, A. and Wilhelm Jr, W. (2008) Investment Banking: Institution, Politics, and Law. Oxford: Oxford University Press.

Powell, J.L. (1984) Least absolute deviations estimation for the censored regression model. Journal of Econometrics, 25: 303-325. 
Powell, J.L. (1986) Censored regression quantiles. Journal of Econometrics, 32: 143-155.

Rajan, R. and Zingales, L. (2003) The great reversals: the politics of financial development in the twentieth century. Journal of Financial Economics, 69: 5-50.

Sala-i-Martin, X.X. (1997) I just ran two million regressions. The American Economic Review: 178-183.

Sarkissian, S., Schill, M. (2004) The overseas listing decision: new evidence of proximity preference. The Review of Financial Studies, 17: 769-809.

Sassen, S., (2001) The global city: New York, London, Tokyo. Princeton: Princeton University Press.

Strange, S. (1986) Casino Capitalism. Manchester: Manchester University Press.

Stulz, R., Williamson, R. (2003) Culture, openness, and finance. Journal of Financial Economics, 70: 313-349.

Tobin, J. (1958) Estimation of relationships for limited dependent variables. Econometrica: Journal of the Econometric Society: 24-36.

Very, P., Schweiger, D. (2001) The acquisition process as a learning process: evidence from a study of critical problems and solutions in domestic and cross-border deals. Journal of World Business, 36: 11-31.

Wang, H.J., Fygenson, M. (2009) Inference for censored quantile regression models in longitudinal studies. The Annals of Statistics: 756-781.

Warf, B. (1989) Telecommunications and the globalization of financial services. The Professional Geographer, 41: 257-271.

Wójcik, D. (2012) The end of investment bank capitalism? An economic geography of financial jobs and power. Economic Geography, 88, 4: 345-368.

Wójcik, D. (2011) The Global Stock Market: Issuers, Investors, and Intermediaries in an Uneven World. Oxford: Oxford University Press.

Wójcik, D., Knight, E., O’Neill, P. and Pažitka, V. (2016) Investment banking since 2008: geography of shrinkage and shift. Financial Geography Working Paper, www.fingeo.net. 
Table 1. Factors of IFC development

\begin{tabular}{|c|c|c|c|}
\hline & \multicolumn{2}{|c|}{ Scale } & \multirow{2}{*}{$\begin{array}{c}\text { Expected } \\
\text { impact }\end{array}$} \\
\hline & City & Country & \\
\hline \multicolumn{4}{|l|}{ Political and legal institutions } \\
\hline Political stability & & $x$ & + \\
\hline Control of corruption & & $x$ & + \\
\hline Protection of property rights & & $x$ & + \\
\hline Rule of law & & $x$ & + \\
\hline Quality of regulation & & $x$ & + \\
\hline Enforcement of contracts & & $x$ & + \\
\hline Protection of creditor rights & & $x$ & + \\
\hline Protection of shareholder rights & & $x$ & + \\
\hline Legal system origin & & $x$ & + \\
\hline Political capital & $x$ & & + \\
\hline \multicolumn{4}{|l|}{ Labour market } \\
\hline Size of the labour market & $x$ & & + \\
\hline Quality of education & $\mathrm{x}$ & $x$ & + \\
\hline Flexibility & & $x$ & + \\
\hline Openness & & $x$ & + \\
\hline English language & & $x$ & + \\
\hline \multicolumn{4}{|l|}{ Infrastructure } \\
\hline Information & $\mathrm{x}$ & & + \\
\hline Transport & $\mathrm{x}$ & & + \\
\hline \multicolumn{4}{|l|}{ Non-financial sector development } \\
\hline Presence of large non-financial firms & $\mathrm{x}$ & $\mathrm{X}$ & + \\
\hline Internationalisation of large non-financial firms & $\mathrm{x}$ & $x$ & + \\
\hline Openness of the domestic economy & & $x$ & + \\
\hline Seaport & $x$ & & $+/ 0$ \\
\hline \multicolumn{4}{|l|}{ Financial sector development } \\
\hline Domestic financial activity & $\mathrm{x}$ & & + \\
\hline Presence of a stock exchange & $\mathrm{x}$ & & $+/ 0$ \\
\hline Stock market development & & $x$ & + \\
\hline Financial market valuations & & $x$ & $+/-$ \\
\hline Presence of large institutional investors & $x$ & $x$ & + \\
\hline Competition in the financial sector & $\mathrm{x}$ & & + \\
\hline Government debt burden & & $x$ & - \\
\hline \multicolumn{4}{|l|}{ Taxation } \\
\hline Personal taxes & & $x$ & - \\
\hline Corporate taxes & & $x$ & $-/ 0$ \\
\hline Taxes specific to financial transactions & & $x$ & $-/ 0$ \\
\hline \multicolumn{4}{|l|}{ Macroeconomic conditions } \\
\hline Real interest rates & & $x$ & - \\
\hline Inflation & & $x$ & - \\
\hline \multicolumn{4}{|l|}{ Other conditions } \\
\hline Greenwhich Mean Time & $\mathrm{x}$ & & + \\
\hline Quality of life & $\mathrm{x}$ & & + \\
\hline
\end{tabular}


Table 2. Top 25 IFCs by cross-border fees totalled over the period $2000-2014$

\begin{tabular}{|c|c|c|c|}
\hline & City & Country & $\begin{array}{l}\text { Cross-border fees } \\
\text { [2012 USD mil] }\end{array}$ \\
\hline 1 & London & Great Britain & 130,943 \\
\hline 2 & New York & United States & 125,242 \\
\hline 3 & Zurich & Switzerland & 100,430 \\
\hline 4 & Frankfurt & Germany & 53,277 \\
\hline 5 & Paris & France & 40,482 \\
\hline 6 & Toronto & Canada & 32,967 \\
\hline 7 & Tokyo & Japan & 22,522 \\
\hline 8 & Amsterdam & Netherlands & 17,948 \\
\hline 9 & Edinburgh & Great Britain & 15,617 \\
\hline 10 & Hong Kong & China & 9,996 \\
\hline 11 & Sydney & Australia & 5,126 \\
\hline 12 & Stockholm & Sweden & 4,437 \\
\hline 13 & Milan & Italy & 3,017 \\
\hline 14 & Brussels & Belgium & 2,905 \\
\hline 15 & Oslo & Norway & 2,791 \\
\hline 16 & Singapore & Singapore & 2,758 \\
\hline 17 & Munich & Germany & 2,513 \\
\hline 18 & Melbourne & Australia & 1,937 \\
\hline 19 & Charlotte, NC & United States & 1,928 \\
\hline 20 & Dusseldorf & Germany & 1,665 \\
\hline 21 & Copenhagen & Denmark & 1,480 \\
\hline 22 & San Francisco & United States & 1,432 \\
\hline 23 & Chicago & United States & 1,043 \\
\hline 24 & Montreal & Canada & 955 \\
\hline 25 & Vienna & Austria & 916 \\
\hline
\end{tabular}

Source: Authors’ calculations based on Dealogic data.

Cross-border fees [2012 USD mil] column represents an inflation adjusted sum of fees earned by financial advisors with operational headquarters in the given city from cross-border deals during the 2000 - 2014 time period. 
Table 3. Correlated-Random-Effects Quantile Regression Results

\begin{tabular}{|c|c|c|c|c|c|c|}
\hline \multirow{3}{*}{ Percentile } & \multicolumn{6}{|c|}{ Dependent variable - LN.Xborder.Fees } \\
\hline & \multicolumn{2}{|l|}{ 99.9th } & \multicolumn{2}{|l|}{ 99th } & \multicolumn{2}{|l|}{ 95th } \\
\hline & Coefficient & t-stat. & Coefficient & t-stat. & Coefficient & t-stat. \\
\hline \multicolumn{7}{|l|}{ City level explanatory variables } \\
\hline Advisor.HF.City & $4.2536 * * *$ & $(2.6401)$ & $3.8346 *$ & $(1.9358)$ & $5.8910 * *$ & $(2.5477)$ \\
\hline Advisor.HF.City.SQ & $-3.9621 * * *$ & $(-2.6219)$ & -3.8467 & $(-1.5457)$ & $-8.0180 * *$ & $(-2.5252)$ \\
\hline Stock.Exchange & $1.7860 * * *$ & $(4.0938)$ & $1.6523 * *$ & $(2.2131)$ & 1.3453 & (1.2018) \\
\hline Top.Dom.Fin.Centre & $1.2208 * * *$ & $(3.5661)$ & $1.5557^{* *}$ & $(2.4788)$ & $2.3431 * * *$ & $(2.6990)$ \\
\hline LN.Population.City & $5.6619 * * *$ & $(3.0612)$ & 4.3514 & $(1.5873)$ & 4.1708 & $(1.1756)$ \\
\hline \multicolumn{7}{|l|}{ Country level explanatory variables } \\
\hline Cost.Enfr.Contract.Pct.Claim.L1 & $-0.2647 * * *$ & $(-3.7642)$ & $-0.2749 * *$ & $(-2.3856)$ & -0.1728 & $(-0.9286)$ \\
\hline Rule.of.Law.L1 & $0.0882 * * *$ & $(6.2776)$ & $0.0915 * * *$ & $(3.3722)$ & $0.1289 * *$ & $(2.0732)$ \\
\hline EU.Member & $1.9272 * *$ & $(2.0719)$ & $2.1416 *$ & $(1.7977)$ & 0.5297 & $(0.3548)$ \\
\hline Foreign.Sales.Pct & $0.0335 *$ & $(1.7520)$ & 0.0192 & $(0.8275)$ & $0.0494 *$ & $(1.7211)$ \\
\hline Real.Int.Rate & $-0.0942 * * *$ & $(-4.4065)$ & $-0.1120 * * *$ & $(-3.8818)$ & -0.0842 & $(-1.5435)$ \\
\hline Inflation.Avg.Prices & $-0.0836 * *$ & $(-2.5277)$ & -0.0694 & $(-1.0776)$ & -0.0063 & $(-0.0591)$ \\
\hline Redundancy.Costs.Weeks & $-0.1355 * * *$ & $(-8.1939)$ & $-0.1473 * * *$ & $(-6.4377)$ & $-0.1708 * * *$ & $(-4.3420)$ \\
\hline Top.500.Uni.Country & $0.0402 * * *$ & $(2.7046)$ & $0.0500 *$ & $(1.9483)$ & 0.0226 & $(0.5868)$ \\
\hline \multicolumn{7}{|l|}{ Correlated random effects terms } \\
\hline (M) Advisor.HF.City & $4.9046 * * *$ & (3.9130) & $5.0579 * * *$ & (3.1379) & $8.1754 * * *$ & $(2.9502)$ \\
\hline (M) LN.Population.City & $-4.5646 * *$ & $(-2.5689)$ & -3.3165 & $(-1.2261)$ & -2.8929 & $(-0.8287)$ \\
\hline (M) Cost.Enfr.Contract.Pct.Claim.L1 & $0.2642 * * *$ & (3.7753) & $0.2774^{* *}$ & $(2.3633)$ & 0.1703 & $(0.9064)$ \\
\hline (M) Rule.of.Law.L1 & $-0.0635 * * *$ & $(-3.3225)$ & $-0.0709 * *$ & $(-2.3772)$ & $-0.1139 * *$ & $(-2.0071)$ \\
\hline (M) EU.Member & -1.7146 & $(-1.6078)$ & -2.1193 & $(-1.2864)$ & -0.2775 & $(-0.1326)$ \\
\hline (M) Foreign.Sales.Pct & -0.0385 & $(-1.3639)$ & -0.0204 & $(-0.5906)$ & 0.0010 & $(0.0222)$ \\
\hline (M) Real.Int.Rate & $0.0709 * * *$ & $(3.7238)$ & $0.0856 * * *$ & $(2.9394)$ & 0.0924 & $(1.0482)$ \\
\hline Time period dummy variables & yes & & yes & & yes & \\
\hline Cross-sections (time periods) & 150 & (15) & 150 & $(15)$ & 150 & (15) \\
\hline
\end{tabular}

*** Significant at $1 \%$ level, ** at $5 \%$ level, * at $10 \%$ level

Table 3 presents the coefficient estimates and their t-statistics in parentheses obtained using a correlated-randomeffects quantile regression (CREQR) estimator proposed by Bache et al. (2013) and available in the R package rqpd. These estimates were derived from a sample of the top 150 cities by average employment in financial and business services over the period 2000 - 2014 sampled from a set of 770 cities available in the Oxford Economics database. The dependent variable for all models presented here is LN.Fees.Xborder, which is a natural logarithm of gross fees from cross-border deals earned by financial advisors located in each city. Cross-border fees have been estimated using data from Dealogic ECM, DCM, Loans and M\&As databases and are presented in more detail in the data section of this paper. Foreign.Sales.Pct is a percentage of foreign sales to total sales averaged across non-financial publicly listed companies in the given country. Real.Int.Rate is a real interest rate and has been sourced from World Development Indicators (WDI) database. Inflation.Avg.Prices is an inflation rate measured at country level and has been calculated based on average annual prices. It has been sourced from the International Monetary Fund (IMF). EU.Member is a binary indicator for whether given country is a member of the European Union or not. Top.Dom.Fin.Centre is a binary indicator, which $=1$ if the given city was the leading financial centre in its country as measured by the gross fees earned from domestic deals and $=0$ otherwise. Top.500.Uni.Country is a count variable measuring the number of universities in each country, which have ranked in the top 500 universities worldwide in the 2014 Times Higher 
Education guide. Redundancy.Costs.Weeks is the statutory number of weeks of salary that employers in the given country are required to pay out to an employee in the event of involuntary redundancy and has been sourced from the 2014-2015 World Economic Forum (WEF) Global Competitivness Report. Stock.Exchange is a binary indicator variable, which $=1$ if the given city has a stock exchange and $=0$ otherwise. Cost.Enfr.Contract.Pct.Claim.L1 is a lagged value (by 1 year) of the cost of enforcement of contracts as a percentage of claim variable and has been sourced from the Doing Business Database (World Bank). Rule.of.Law.L1 is a lagged value of country's percentile ranking in terms of rule of law and has been sourced from the World Development Indicators (WDI) database (World Bank). LN.Population.City is a natural logarithm of city's population and has been sourced from the Oxford Economics - Global Cities database. Advisor.HF.City is the herfindahl index calculated based on the market shares of financial advisors (in terms of gross underwriting revenue) at city level. For cities with fewer then 5 advisors the calculated value has been replaced by zero in order to avoid spuriously high concentration levels being calculated, when insufficient number of advisors has been allocated to the given city. Advisor.HF.City.SQ is a squared value of the previous variable and has been included to allow for a non-linear (quadratic) effect. Variables in the bottom section of the table starting with (M) represent the correlated random effects (CRE) terms, which have been constructed as the averages of the concerned variables for each cross-section following the methodology proposed by Bache et al. (2013). Tau ( $\tau$ ) at the top of each column represents the conditional quantile being estimated (e.g. $0.99=$ 99th percentile). Standard errors of the coefficient estimates have been calculated using the generalized bootstap procedure of Bose and Chatterjee (2003) with unit exponential weights and repeated sampling of cross-sections (cities) rather than individual observations to account for the dependence between observations given by the longitudinal structure of this dataset. 

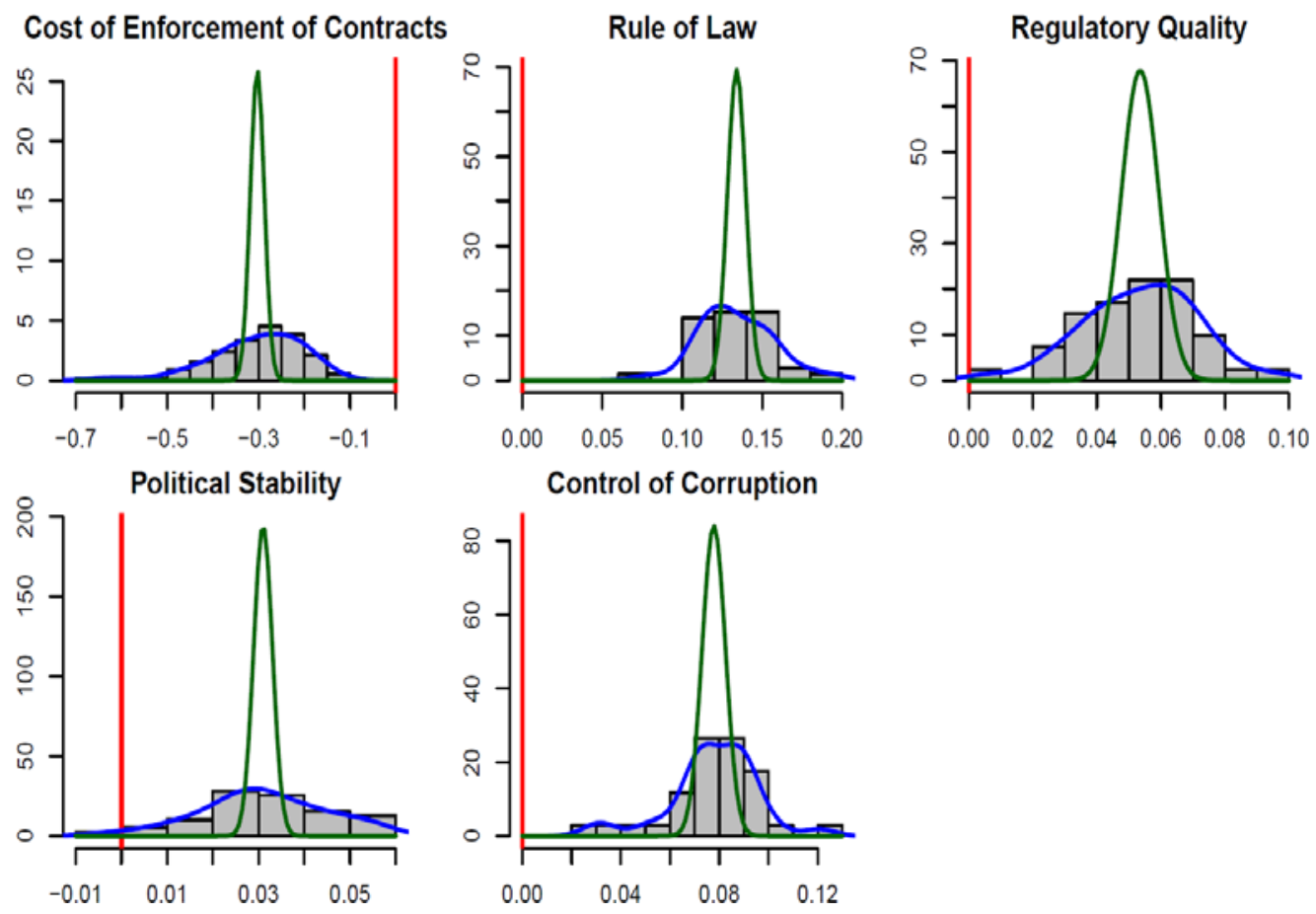

The histograms displayed above represent the empirical distributions of coefficient estimates of cost of enforcement of contracts, rule of law, regulatory quality, political stability and control of corruption. The blue line represents kernel density curve and the green line represents a normal distribution with the same mean and variance as that of our coefficient estimates for comparison. Horizontal axis represents the values of coefficient estimates and the vertical axis represents the corresponding probability density. Comprehensive EBA report is available in appendix II.

Figure 1. EBA results for selected institutional variables. 


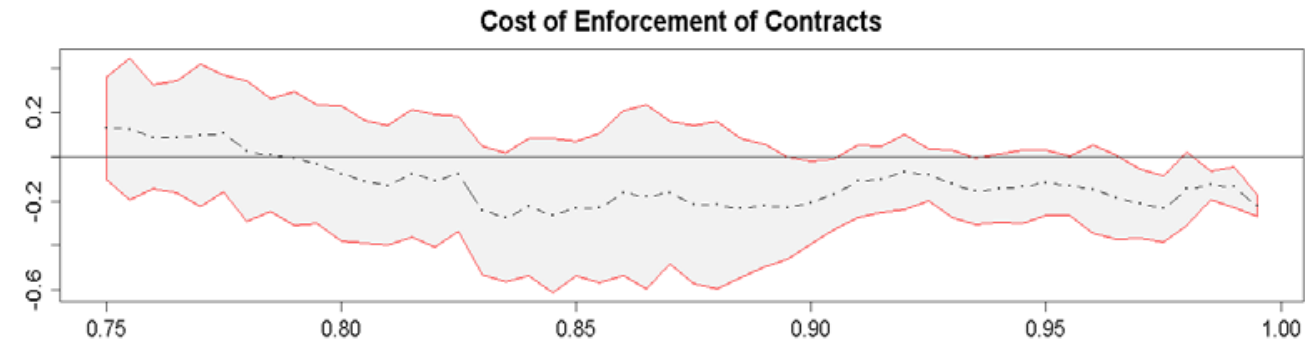

Rule of Law

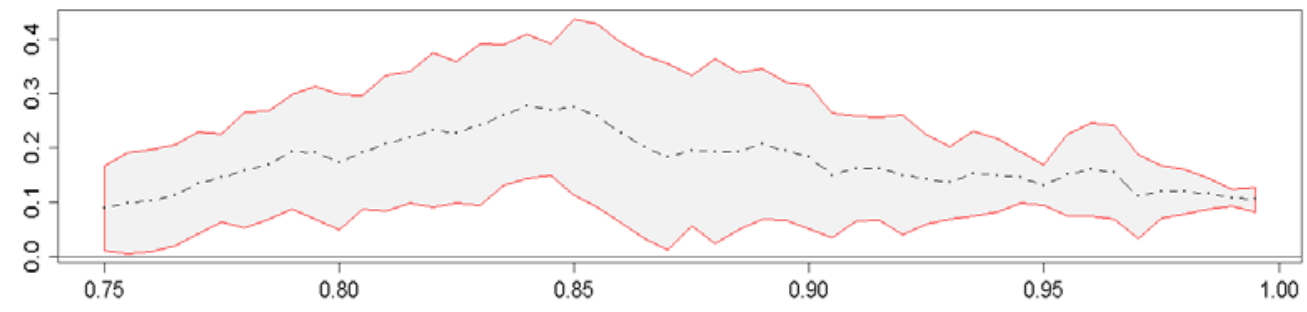

The horizontal axis represents conditional quantiles at which the coefficients were estimated. Vertical axis represents the magnitude of the coefficient estimates. The grey polygon with red borders represents the 95 per cent confidence interval for the coefficient estimates. The black horizontal line represents zero and can be used to construct tests of statistical significance by examining whether the $95 \%$ confidence interval of coefficient estimates crosses this line. If the confidence interval crosses the black horizontal line going through zero, the given coefficient estimate is not statistically significantly different from zero at $5 \%$ level. Both plots are based on the model detailed in table 5 .

Figure 2. Effects of legal variables across conditional quantiles. 


\section{Rule of Law}

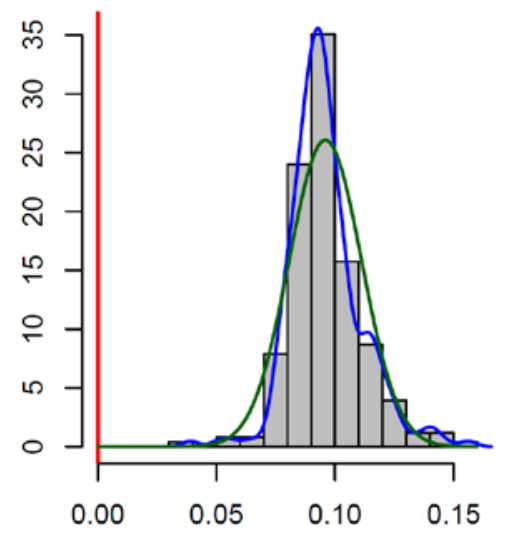

\section{Cost of Enforcement of Contracts}

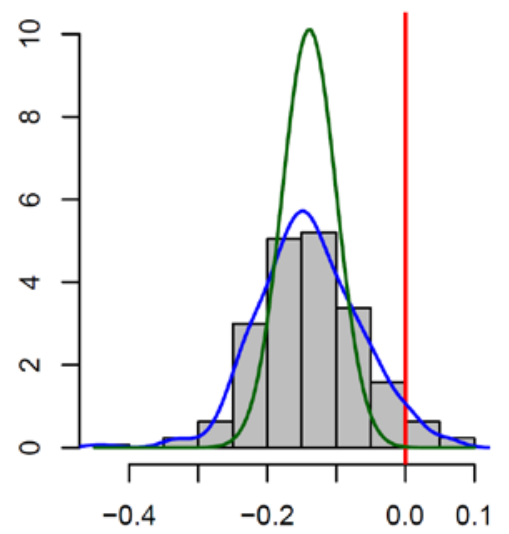

The histograms displayed above represent the empirical distributions of coefficient estimates on cost of enforcement of contracts and rule of law, which were obtained from and extreme bounds analysis implemented in R package 'ExtremeBounds'. The blue line represents the kernel density curve and the green line represents a normal distribution with the same mean and variance as that of our coefficient estimates for comparison. Horizontal axis represents the values of coefficient estimates and the vertical axis represents the corresponding probability density. The full report of EBA is available in appendix III.

Figure 3. Rule of law and cost of enforcement EBA. 


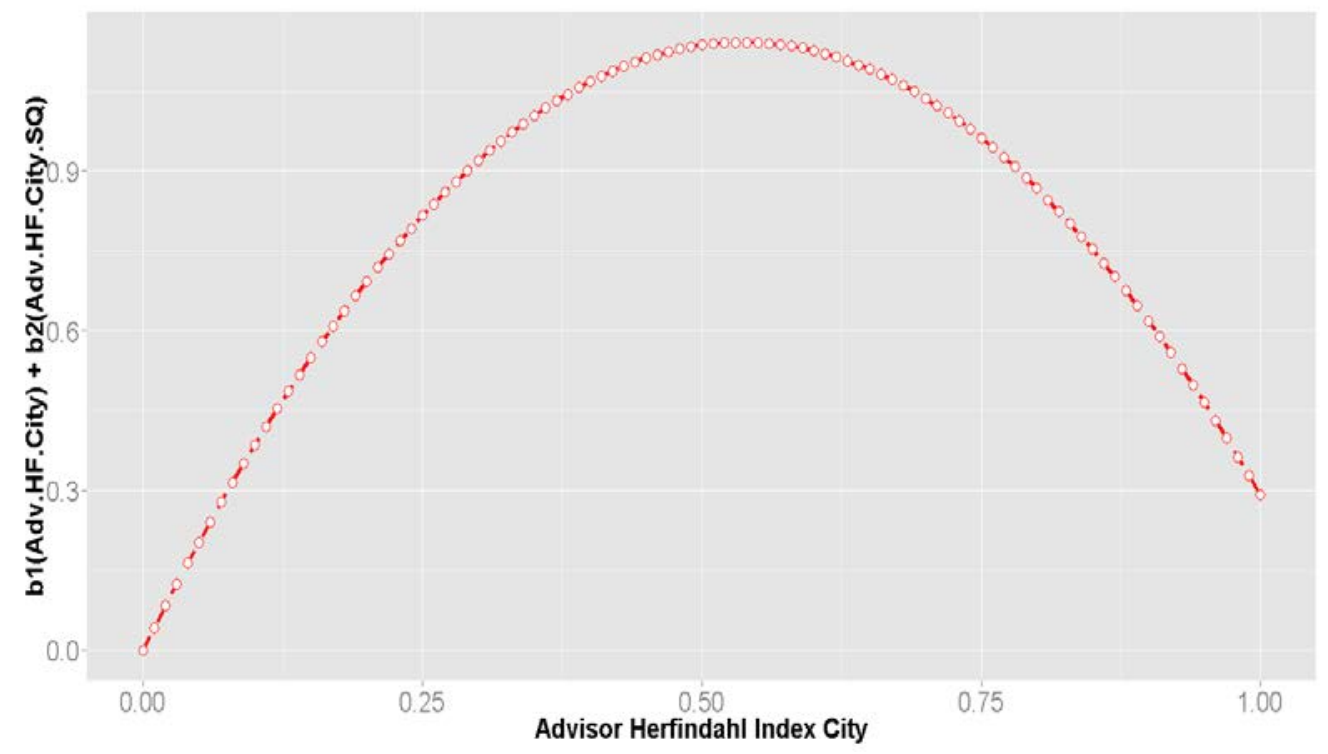

The horizontal axis represents the full range of possible values of advisor Herfindahl index at a city level. The vertical axis represents the effect of concentration in the financial advisory cross-border market (at city level) on the natural logarithm of cross-border fees. The maximum of this quadratic function is at Herfindahl index of 0.5368 . Coefficient estimates used for plotting this quadratic function were drawn from table 5.

Figure 4. Relationship between market concentration and cross-border fees 
Table A1. Variable definitions and data sources

\begin{tabular}{|c|c|c|}
\hline & Definition & Source \\
\hline \multicolumn{3}{|l|}{ Fees and employment } \\
\hline LN.Fees.Xborder & $\begin{array}{l}\text { Natural logarithm of the sum of cross-border fees earned by } \\
\text { financial advisors across ECM, DCM, syndicated loans and } \\
\text { M\&A services in the given metropolitan statistical area (MSA) } \\
\text { / year. }\end{array}$ & $\begin{array}{l}\text { Author's } \\
\text { calculations } \\
\text { based on } \\
\text { Dealogic ECM, } \\
\text { DCM, Loans and } \\
\text { M\&As databases }\end{array}$ \\
\hline Employ.FABS.City.Mean & $\begin{array}{l}\text { Average employment for } 2000 \text { - } 2014 \text { in the financial and } \\
\text { business services sector (as defined by Oxford Economics - } \\
\text { Global Cities) at city level. }\end{array}$ & $\begin{array}{l}\text { Oxford } \\
\text { Economics - } \\
\text { Global Cities } \\
\text { (OE Glob. } \\
\text { Cities) }\end{array}$ \\
\hline \multicolumn{3}{|l|}{$\begin{array}{l}\text { Political and legal } \\
\text { institutions }\end{array}$} \\
\hline Political.Stabl.Rank & $\begin{array}{l}\text { Percentile ranking index based on political stability, absence of } \\
\text { violence and terrorism of countries. }\end{array}$ & $\begin{array}{l}\text { World } \\
\text { Development } \\
\text { Indicators (WDI) } \\
\text { database - World } \\
\text { Bank }\end{array}$ \\
\hline Ctrl.Corruption.Rank & $\begin{array}{l}\text { Percentile ranking index based on control of corruption of } \\
\text { countries. }\end{array}$ & WDI database \\
\hline Property.Rights & $\begin{array}{l}\text { Survey based measure; Q: In your country, how strong is the } \\
\text { protection of property rights, including financial assets? [1 = } \\
\text { extremely weak; } 7 \text { = extremely strong] | 2013-14 weighted } \\
\text { average }\end{array}$ & $\begin{array}{l}\text { World Economic } \\
\text { Forum - Global } \\
\text { Competitiveness } \\
\text { Report } 2014 \text { - } \\
2015 \text { (WEF) }\end{array}$ \\
\hline Rule.of.Law & Percentile ranking index of countries by rule of law & WDI database \\
\hline Regul.Qual.Rank & $\begin{array}{l}\text { Percentile ranking index based on regulatory quality of } \\
\text { countries. }\end{array}$ & WDI database \\
\hline Cost.Enfr.Contract.Pct.Claim & $\begin{array}{l}\text { Cost of enforcement of contracts measured as a percentage of } \\
\text { claim. }\end{array}$ & $\begin{array}{l}\text { Doing Business } \\
\text { (DB) database - } \\
\text { World Bank }\end{array}$ \\
\hline Creditor.Rights.Djankov2007 & Creditor rights index & $\begin{array}{l}\text { Djankov et al. } \\
(2007)\end{array}$ \\
\hline Investor.Prot.Index & Investor Protection Index & DB database \\
\hline English.Common.Law & $\begin{array}{l}\text { Binary indicator variable; = } 1 \text { if the legal system of the given } \\
\text { country is of English Common Law origin and = } 0 \text { otherwise. }\end{array}$ & $\begin{array}{l}\text { The World } \\
\text { Factbook (CIA) }\end{array}$ \\
\hline French.Civil.Law & $\begin{array}{l}\text { Binary indicator variable; = } 1 \text { if the legal system of the given } \\
\text { country is of French Civil Law origin and = } 0 \text { otherwise. }\end{array}$ & CIA \\
\hline Political.Capital & $\begin{array}{l}\text { Binary indicator variable; }=1 \text { if the given MSA includes the } \\
\text { political capital of the given country and = } 0 \text { otherwise. }\end{array}$ & CIA \\
\hline \multicolumn{3}{|l|}{$\begin{array}{l}\text { Labour market } \\
\text { characteristics }\end{array}$} \\
\hline LN.Population.City & Natural logarithm of population of MSA in the given year & OE Glob. Cities \\
\hline Top.100.Uni.City & $\begin{array}{l}\text { Count variable; Number of top } 100 \text { universities based on the } \\
\text { Times Higher Education Guide } 2014 \text { located in the given city. }\end{array}$ & $\begin{array}{l}\text { Times Higher } \\
\text { Education Guide } \\
2014 \text { (THEG } \\
\text { 2014) }\end{array}$ \\
\hline Top.100.Uni.Country & $\begin{array}{l}\text { Count variable; Number of top } 100 \text { universities based on the } \\
\text { Times Higher Education Guide } 2014 \text { located in the given } \\
\text { country. }\end{array}$ & THEG 2014 \\
\hline Top.500.Uni.City & $\begin{array}{l}\text { Count variable; Number of top } 500 \text { universities based on the } \\
\text { Times Higher Education Guide } 2014 \text { located in the given city. }\end{array}$ & THEG 2014 \\
\hline
\end{tabular}




\begin{tabular}{lll}
\hline \multirow{2}{*}{ Top.500.Uni.Country } & \multicolumn{1}{c}{ Definition } & \multicolumn{1}{c}{ Source } \\
\cline { 2 - 3 } Redundancy.Costs.Weeks & $\begin{array}{l}\text { Count variable; Number of top 500 universities based on the } \\
\text { Times Higher Education Guide 2014 located in the given } \\
\text { country. }\end{array}$ & THEG 2014 \\
& $\begin{array}{l}\text { Number of weeks of salary required by companies to pay out } \\
\text { to their employees as a statutory redundancy payment. } \\
\text { English.Language }\end{array}$ & WEF \\
& $\begin{array}{l}\text { Binary indicator variable; = 1 if the official language of a } \\
\text { country is the English language and = 0 otherwise }\end{array}$ & CIA \\
EU.Member & $\begin{array}{l}\text { Binary indicator variable; = 1 if the given country was a } \\
\text { member of the European Union in the given year and =0 } \\
\text { otherwise. }\end{array}$ & $\begin{array}{l}\text { http://europa.eu/a } \\
\text { bout- } \\
\text { eu/countries/inde } \\
\text { x_en.htm }\end{array}$
\end{tabular}

\section{Infrastructure}

LN.Secure.Net.Servers

LN.Metro.Stations

Natural logarithm of the number of secure internet servers per 1 million people

Natural logarithm of the number of metro stations in the given MSA.

WDI database

Metro Bits

website -

http://mic-

ro.com/metro/tab

le.html?feat=CIC

OOPLGSTLSDP

\&orderby $=\mathrm{CI} \& \mathrm{~s}$

ort=ASC\&unit $=$

\&status $=$

\section{Non-financial sector \\ development}

HQ.10bn.Count.City

HQ.10bn.Count.Country

Foreign.Sales.Pct

Exp.Imp.Pct.GDP

LN.Seaport.TEU

Financial sector development

Top.Dom.Fin.Centre

Stock.Exchange
Binary indicator; = 1 if the given MSA was the leading financial centre in the given country by gross fees from domestic deals and $=0$ otherwise.

Binary indicator; = 1 if the given MSA had at least one stock exchange and $=0$ otherwise
Number of companies (both privately or publicly held) with assets of USD 10 billion with operational headquarters in the given MSA.

Number of companies (both privately or publicly held) with assets of USD 10 billion with operational headquarters in the given country.

(\%) foreign sales to total sales of publicly listed companies in the given country / year

Exports + Imports as a percentage of GDP

Natural logarithm of thousands of twenty-foot equivalent units (TEU) transported through the seaport location in the given MSA. If there is no seaport in the given MSA, then $=0$.

The

The Lloyd's List of the World's

Busiest

Container Ports

2013

Authors'

calculations

based on Orbis

data

Authors'

calculations

based on Orbis

data

Author's

calculations

based on data

Worldscope data

WDI database

Author's

calculations

based on

Dealogic data

World

Federation of

Exchanges

website and

websites of

individual stock

exchanges 


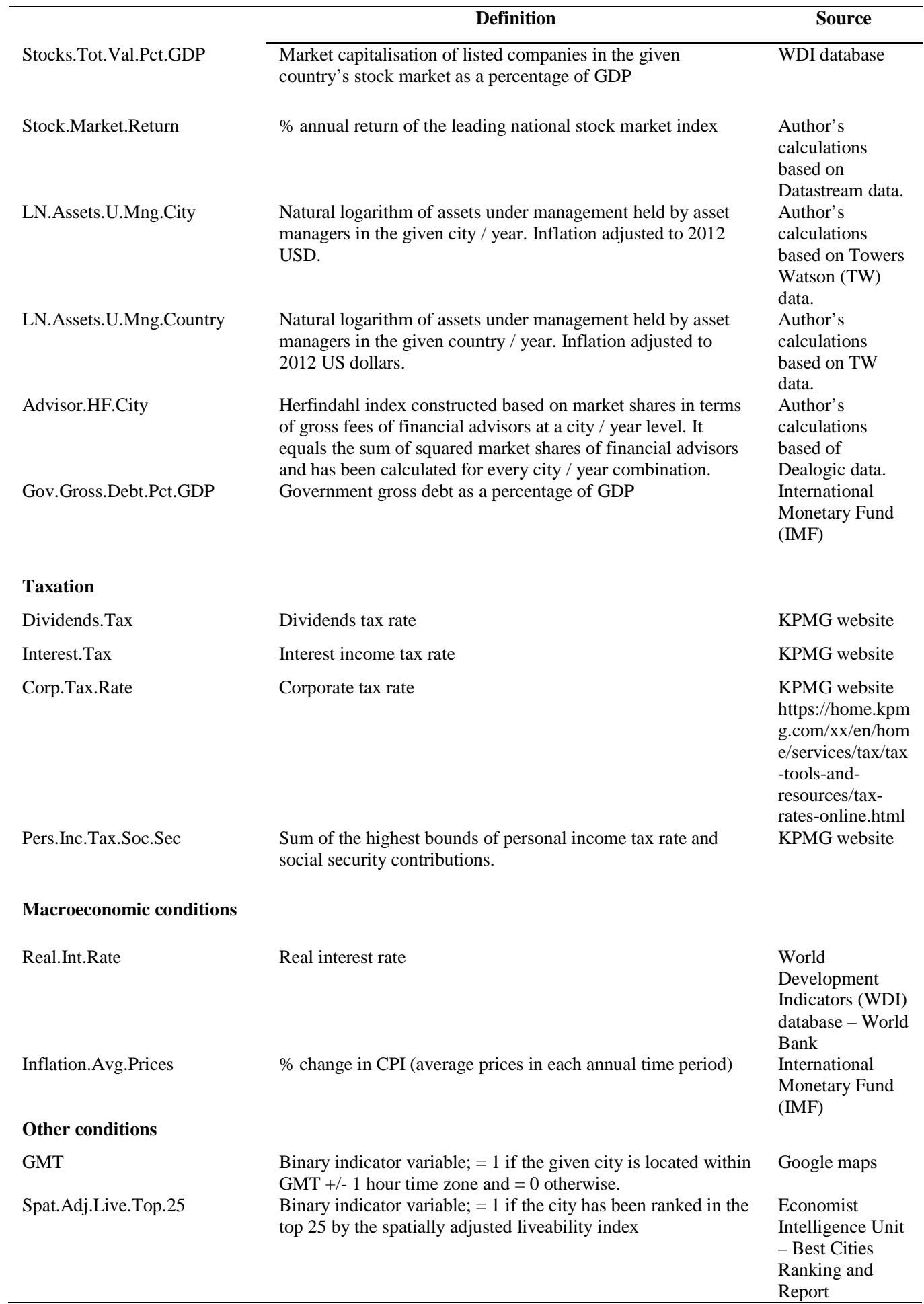


Table A2. Descriptive statistics

\begin{tabular}{|c|c|c|c|c|c|c|c|c|c|}
\hline & $\mathbf{N}$ & $x=0$ & Missing & Min & Median & Mean & Max & Sum & SD \\
\hline \multicolumn{10}{|c|}{ Cross-border fees and employment } \\
\hline Xborder.Fees & 2250 & 1125 & 0 & 0.00 & 18.55 & $257,248,350.85$ & $14,264,224,848.10$ & $578,808,789,405.45$ & $1,231,803,452.43$ \\
\hline Employ.FABS.City.Mean & 2250 & 0 & 0 & 149.53 & 278.35 & 422.98 & $3,190.73$ & $951,698.47$ & 437.50 \\
\hline \multicolumn{10}{|l|}{ Political and legal institutions } \\
\hline Political.Stabl.Rank & 2250 & 0 & 0 & 0.94 & 55.29 & 51.53 & 100.00 & $115,946.38$ & 24.02 \\
\hline Ctrl.Corruption.Rank & 2250 & 0 & 0 & 0.96 & 85.02 & 69.29 & 100.00 & $155,905.93$ & 25.81 \\
\hline Property.Rights & 2220 & 0 & 30 & 2.50 & 5.30 & 4.88 & 6.20 & $10,825.50$ & 0.83 \\
\hline Rule.of.Law.Rank & 2250 & 0 & 0 & 1.91 & 86.06 & 69.70 & 100.00 & $156,831.91$ & 26.08 \\
\hline Regul.Qual.Rank & 2250 & 0 & 0 & 2.87 & 83.25 & 72.34 & 100.00 & $162,769.21$ & 24.29 \\
\hline Cost.Enfr.Contract.Pct.Claim & 2250 & 0 & 0 & 10.30 & 18.40 & 22.50 & 139.40 & $50,631.30$ & 14.43 \\
\hline Creditor.Rights.Djankov2007 & 2220 & 150 & 30 & 0.00 & 2.00 & 1.75 & 4.00 & $3,885.00$ & 0.99 \\
\hline Investor.Prot.Index.DB & 2250 & 0 & 0 & 1.70 & 6.00 & 6.33 & 9.30 & $14,241.60$ & 1.68 \\
\hline English.Common.Law & 2250 & 1230 & 0 & 0.00 & 0.00 & 0.45 & 1.00 & $1,020.00$ & 0.50 \\
\hline French.Civil.Law & 2250 & 1695 & 0 & 0.00 & 0.00 & 0.25 & 1.00 & 555.00 & 0.43 \\
\hline Political.Capital & 2250 & 1620 & 0 & 0.00 & 0.00 & 0.28 & 1.00 & 630.00 & 0.45 \\
\hline \multicolumn{10}{|l|}{ Labour market } \\
\hline Total.Population.City & 2193 & 0 & 57 & $1,254.13$ & $4,228.11$ & $6,290.53$ & $37,027.83$ & $13,795,121.69$ & $5,734.53$ \\
\hline Top.100.Uni.City & 2250 & 1620 & 0 & 0.00 & 0.00 & 0.70 & 6.00 & $1,575.00$ & 1.22 \\
\hline Top.100.Uni.Country & 2250 & 1200 & 0 & 0.00 & 0.00 & 14.23 & 53.00 & $32,010.00$ & 22.31 \\
\hline Top.500.Uni.City & 2250 & 630 & 0 & 0.00 & 2.00 & 2.37 & 11.00 & $5,340.00$ & 2.22 \\
\hline Top.500.Uni.Country & 2250 & 780 & 0 & 0.00 & 5.00 & 12.11 & 40.00 & $27,255.00$ & 14.26 \\
\hline Redundancy.Costs.Weeks & 2220 & 570 & 30 & 0.00 & 12.00 & 13.44 & 57.80 & $29,829.00$ & 11.11 \\
\hline EU.Member & 2250 & 1753 & 0 & 0.00 & 0.00 & 0.22 & 1.00 & 497.00 & 0.41 \\
\hline English.Language & 2250 & 1275 & 0 & 0.00 & 0.00 & 0.43 & 1.00 & 975.00 & 0.50 \\
\hline \multicolumn{10}{|l|}{ Infrastructure } \\
\hline Secure.Net.Servers & 1922 & 0 & 328 & 0.01 & 162.48 & 478.84 & $2,820.43$ & $920,331.07$ & 588.53 \\
\hline Metro.Stations & 2250 & 947 & 0 & 0.00 & 19.00 & 49.71 & 472.00 & $111,838.00$ & 81.27 \\
\hline \multicolumn{10}{|c|}{ Non-financial sector development } \\
\hline HQ.10bn.Count.City & 2250 & 420 & 0 & 0.00 & 5.00 & 13.35 & 246.00 & $30,045.00$ & 28.05 \\
\hline HQ.10bn.Count.Country & 2250 & 135 & 0 & 0.00 & 106.00 & 136.12 & 308.00 & $306,270.00$ & 113.89 \\
\hline Foreign.Sales.Pct & 2134 & 9 & 116 & 0.00 & 20.47 & 25.83 & 86.11 & $55,117.92$ & 15.38 \\
\hline Exp.Imp.Pct.GDP & 2182 & 0 & 68 & 20.26 & 48.83 & 57.38 & 455.28 & $125,213.68$ & 49.36 \\
\hline Seaport.TEU & 2250 & 1635 & 0 & 0.00 & 0.00 & $1,899.67$ & $33,617.00$ & $4,274,260.00$ & $5,025.15$ \\
\hline \multicolumn{10}{|l|}{ Financial sector development } \\
\hline Top.Dom.Fin.Centre & 2250 & 1681 & 0 & 0.00 & 0.00 & 0.25 & 1.00 & 569.00 & 0.43 \\
\hline Stock.Exchange & 2250 & 1170 & 0 & 0.00 & 0.00 & 0.48 & 1.00 & $1,080.00$ & 0.50 \\
\hline Stocks.Tot.Val.Pct.GDP & 1907 & 0 & 343 & 0.04 & 73.68 & 110.38 & 741.59 & $210,487.74$ & 103.55 \\
\hline Stock.Market.Return & 2099 & 0 & 151 & -1.60 & 0.08 & 0.03 & 0.99 & 62.60 & 0.31 \\
\hline Assets.U.Mng.City & 900 & 444 & 1350 & 0.00 & 1.00 & $392,867.63$ & $14,382,293.00$ & $353,580,868.00$ & $1,282,026.50$ \\
\hline Assets.U.Mng.Country & 900 & 168 & 1350 & 0.00 & $641,594.00$ & $7,910,896.66$ & $32,173,639.00$ & $7,119,806,990.00$ & $11,754,041.70$ \\
\hline Advisor.HF.City & 2250 & 1413 & 0 & 0.00 & 0.00 & 0.10 & 0.95 & 231.45 & 0.17 \\
\hline Gov.Gross.Debt.Pct.GDP & 2206 & 0 & 44 & 3.22 & 62.07 & 63.17 & 246.42 & $139,354.78$ & 34.96 \\
\hline \multicolumn{10}{|l|}{ Taxation } \\
\hline Dividends.Tax & 2190 & 375 & 60 & 0.00 & 15.75 & 16.98 & 35.00 & $37,182.00$ & 11.01 \\
\hline Interest.Tax & 2205 & 210 & 45 & 0.00 & 15.00 & 13.56 & 30.00 & $29,899.20$ & 5.92 \\
\hline Corp.Tax.Rate & 1933 & 0 & 317 & 10.00 & 33.00 & 32.25 & 40.69 & $62,330.02$ & 6.97 \\
\hline Pers.Inc.Tax.Soc.Sec & 1524 & 0 & 726 & 13.00 & 42.65 & 46.00 & 83.15 & $70,107.02$ & 12.26 \\
\hline \multicolumn{10}{|l|}{ Macroeconomic conditions } \\
\hline Real.Int.Rate & 1953 & 0 & 297 & -60.80 & 3.09 & 5.52 & 48.71 & $10,784.94$ & 9.86 \\
\hline Inflation.Avg.Prices & 2248 & 1 & 2 & -3.72 & 2.74 & 3.99 & 325.03 & $8,967.36$ & 9.27 \\
\hline \multicolumn{10}{|l|}{ Other conditions } \\
\hline GMT & 2250 & 1725 & 0 & 0.00 & 0.00 & 0.23 & 1.00 & 525.00 & 0.42 \\
\hline Spat.Adj.Live.Top.25 & 2250 & 1890 & 0 & 0.00 & 0.00 & 0.16 & 1.00 & 360.00 & 0.37 \\
\hline
\end{tabular}


Table A3. Extreme bounds analysis - institutional variables

\begin{tabular}{|c|c|c|c|c|c|c|c|}
\hline & Type & Coef (Mean) & SE (Mean) & Pct(sig \& beta $<0)$ & Pct(sig \& beta $>0$ ) & G: $\operatorname{CDF}($ beta $<=0)$ & G: $\mathrm{CDF}($ beta $>0)$ \\
\hline \multicolumn{8}{|l|}{ Political and legal institutions } \\
\hline Political.Stabl.Rank.L1 & focus & 0.0310 & 0.0100 & 0.0000 & 78.3780 & 4.829 & 95.171 \\
\hline Ctrl.Corruption.Rank.L1 & focus & 0.0710 & 0.0260 & 0.0000 & 79.4870 & 2.91 & 97.09 \\
\hline Rule.of.Law.Rank.L1 & focus & 0.1380 & 0.0210 & 0.0000 & 100.0000 & 0.002 & 99.998 \\
\hline Regul.Qual.Rank.L1 & focus & 0.0470 & 0.0330 & 0.0000 & 35.0000 & 13.659 & 86.341 \\
\hline Cost.Enfr.Contract.Pct.Claim.L1 & free & -0.2930 & 0.0740 & 88.0000 & 0.0000 & 98.9700 & 1.0300 \\
\hline Property.Rights & focus & -0.5390 & 0.3250 & 40.0000 & 2.2220 & 79.416 & 20.584 \\
\hline Investor.Prot.Index & focus & 0.1590 & 0.0930 & 2.0000 & 52.0000 & 15.416 & 84.584 \\
\hline Creditor.Rights.Djankov2007 & focus & -0.6100 & 0.1340 & 89.0910 & 0.0000 & 92.516 & 7.484 \\
\hline English.Common.Law & focus & 2.2190 & 0.4560 & 0.0000 & 100.0000 & 0.187 & 99.813 \\
\hline French.Civil.Law & focus & -0.8580 & 0.4530 & 42.8570 & 0.0000 & 83.283 & 16.717 \\
\hline Political.Capital & focus & 0.5580 & 0.2040 & 0.0000 & 80.0000 & 1.065 & 98.935 \\
\hline \multicolumn{8}{|l|}{ Labour market } \\
\hline LN.Population.City & free & 6.6840 & 1.7490 & 0.0000 & 86.0000 & 1.6490 & 98.3510 \\
\hline Top.100.Uni.City & focus & 0.1440 & 0.0870 & 0.0000 & 30.0000 & 10.358 & 89.642 \\
\hline Top.100.Uni.Country & focus & -0.0320 & 0.0110 & 100.0000 & 0.0000 & 99.219 & 0.781 \\
\hline Top.500.Uni.City & focus & 0.0520 & 0.0390 & 0.0000 & 40.0000 & 15.313 & 84.687 \\
\hline Top.500.Uni.Country & focus & 0.0400 & 0.0150 & 0.0000 & 25.0000 & 4.299 & 95.701 \\
\hline EU.Member & free & 1.4530 & 0.3440 & 1.3330 & 84.0000 & 7.5960 & 92.4040 \\
\hline Redundancy.Costs. Weeks & free & -0.0910 & 0.0220 & 89.3330 & 0.0000 & 99.1440 & 0.8560 \\
\hline English.Language & focus & 2.3670 & 0.5080 & 0.0000 & 100.0000 & 0.28 & 99.72 \\
\hline \multicolumn{8}{|l|}{ Infrastructure } \\
\hline LN.Secure.Net.Servers & focus & -0.1360 & 0.2590 & 12.5000 & 0.0000 & 60.805 & 39.195 \\
\hline LN.Metro.Stations & focus & -0.0710 & 0.0550 & 33.3330 & 0.0000 & 80.664 & 19.336 \\
\hline \multicolumn{8}{|l|}{ Non-financial sector development } \\
\hline HQ.10bn.Count.City & focus & 0.0080 & 0.0020 & 0.0000 & 87.5000 & 1.027 & 98.973 \\
\hline HQ.10bn.Count.Country & focus & -0.0090 & 0.0020 & 100.0000 & 0.0000 & 99.71 & 0.29 \\
\hline Foreign.Sales.Pct & free & 0.0280 & 0.0230 & 0.0000 & 38.0000 & 18.6260 & 81.3740 \\
\hline Exp.Imp.Pct.GDP & focus & 0.0000 & 0.0020 & 0.0000 & 40.0000 & 40.492 & 59.508 \\
\hline LN.Seaport.TEU & focus & -0.2090 & 0.0190 & 100.0000 & 0.0000 & 100 & 0 \\
\hline \multicolumn{8}{|l|}{ Financial sector development } \\
\hline Top.Dom.Fin.Centre & free & 1.7390 & 0.2280 & 0.0000 & 100.0000 & 0.0110 & 99.9890 \\
\hline Stock.Exchange & free & 0.8720 & 0.2350 & 5.3330 & 66.6670 & 18.1540 & 81.8460 \\
\hline Stock. Market.Return & focus & -0.8770 & 0.3230 & 66.6670 & 0.0000 & 91.444 & 8.556 \\
\hline Advisor.HF.City & free & 2.0560 & 1.2690 & 0.6670 & 36.6670 & 22.6500 & 77.3500 \\
\hline Advisor.HF.SQ.City & free & -3.1820 & 1.7430 & 48.0000 & 0.6670 & 82.4460 & 17.5540 \\
\hline Gov.Gross.Debt.Pct.GDP & focus & -0.0200 & 0.0040 & 75.0000 & 0.0000 & 97.287 & 2.713 \\
\hline \multicolumn{8}{|l|}{ Taxation } \\
\hline Corp.Tax.Rate & focus & 0.0820 & 0.0260 & 0.0000 & 85.7140 & 0.726 & 99.274 \\
\hline Dividends.Tax.Pct & focus & -0.0280 & 0.0120 & 50.0000 & 0.0000 & 96.35 & 3.65 \\
\hline Interest.Tax.Pct & focus & -0.0230 & 0.0320 & 20.0000 & 0.0000 & 65.302 & 34.698 \\
\hline Pers.Inc.Tax.Soc.Sec & focus & -0.0040 & 0.0130 & 50.0000 & 0.0000 & 58.232 & 41.768 \\
\hline \multicolumn{8}{|l|}{ Macroeconomic conditions } \\
\hline Real.Int.Rate & free & -0.0330 & 0.0220 & 38.6670 & 0.6670 & 85.3130 & 14.6870 \\
\hline Inflation.Avg.Prices & free & -0.1600 & 0.0640 & 60.6670 & 0.0000 & 95.5120 & 4.4880 \\
\hline \multicolumn{8}{|l|}{ Other conditions } \\
\hline Spat.Adj.Live.Top.25 & focus & 1.3440 & 0.2250 & 0.0000 & 100.0000 & 0 & 100 \\
\hline GMT & focus & 2.5910 & 0.9090 & 0.0000 & 75.0000 & 3.05 & 96.95 \\
\hline \multicolumn{8}{|l|}{ Correlated random effects terms } \\
\hline (M) Foreign.Sales.Pct & free & -0.0280 & 0.0290 & 24.0000 & 0.6670 & 76.7190 & 23.2810 \\
\hline (M) Inflation.Avg.Prices & free & 0.3590 & 0.0980 & 0.0000 & 83.3330 & 1.5990 & 98.4010 \\
\hline (M) Advisor.HF.City & free & 7.3180 & 0.7850 & 0.0000 & 100.0000 & 0.0120 & 99.9880 \\
\hline (M) Cost.Enfr.Contract.Pct.Claim.L1 & free & 0.2840 & 0.0750 & 0.0000 & 89.3330 & 1.1720 & 98.8280 \\
\hline (M) Political.Stabl.Rank.L1 & free & 0.0460 & 0.0120 & 0.0000 & 77.3330 & 6.3530 & 93.6470 \\
\hline (M) Regul.Qual.Rank.L1 & free & -0.0310 & 0.0380 & 32.6670 & 14.6670 & 63.0160 & 36.9840 \\
\hline (M) Ctrl.Corruption.Rank.L1 & free & -0.0210 & 0.0470 & 27.3330 & 16.0000 & 57.7590 & 42.2410 \\
\hline (M) Rule.of.Law.Rank.L1 & free & 0.0040 & 0.0230 & 22.6670 & 33.3330 & 42.4770 & 57.5230 \\
\hline (M) LN.Population.City & free & -5.0110 & 1.7420 & 71.3330 & 0.0000 & 95.3300 & 4.6700 \\
\hline
\end{tabular}

Free variables have been included in every model estimated as part of the EBA routine. Focus variables have been included in groups of three in each model. In every model there has been exactly one institutional variable (rule of law / political stability / regulatory quality / control of corruption) included in addition to cost of enforcement of contracts, which has been always included. Random sample of 150 models has been drawn and estimated. Variables starting with (M) are CRE terms (average of those variables for each cross-section) constructed to control for the correlation 
between these regressors and the error term, due to their relationship with the time constant unobserved heterogeneity.

This approach for dealing with unobserved heterogeneity has been introduced by Bache et al. (2013). Time period dummy variables (Y2002-Y2014) have been included in every model in addition to a common intercept. 
Table A4. Extreme bounds analysis - rule of law

\begin{tabular}{|c|c|c|c|c|c|c|c|}
\hline & Type & Coef (Mean) & SE (Mean) & Pct(signif \& beta $<0$ ) & Pct(signif \& beta >0) & G: $\operatorname{CDF}($ beta $<=0)$ & G: CDF(beta >0) \\
\hline \multicolumn{8}{|l|}{ Political and legal institutions } \\
\hline Cost.Enfr.Contract.Pct.Claim.L1 & free & -0.1390 & 0.0390 & 78.3460 & 0.0000 & 94.5420 & 5.4580 \\
\hline Rule.of.Law.Rank.L1 & free & 0.0960 & 0.0150 & 0.0000 & 100.0000 & 0.0210 & 99.9790 \\
\hline Political.Capital & focus & 0.1570 & 0.1700 & 8.6960 & 17.3910 & 43.9520 & 56.0480 \\
\hline English.Common.Law & focus & 0.5340 & 0.1440 & 5.0000 & 75.0000 & 8.5130 & 91.4870 \\
\hline French.Civil.Law & focus & 0.2270 & 0.2120 & 10.0000 & 30.0000 & 28.5060 & 71.4940 \\
\hline Creditor.Rights.Djankov2007 & focus & -0.1320 & 0.0740 & 57.1430 & 9.5240 & 84.2540 & 15.7460 \\
\hline Investor.Prot.Index & focus & -0.1980 & 0.0540 & 76.1900 & 0.0000 & 96.6200 & 3.3800 \\
\hline Property.Rights & focus & -0.3060 & 0.1140 & 76.1900 & 4.7620 & 87.0370 & 12.9630 \\
\hline \multicolumn{8}{|l|}{ Labour market } \\
\hline EU.Member & free & 0.2110 & 0.2130 & 13.7800 & 41.7320 & 32.6500 & 67.3500 \\
\hline Redundancy.Costs.Weeks & free & -0.1320 & 0.0080 & 100.0000 & 0.0000 & 99.9930 & 0.0070 \\
\hline LN.Population.City & free & 8.2450 & 0.8730 & 0.0000 & 99.6060 & 0.0210 & 99.9790 \\
\hline Top.100.Uni.City & focus & 0.1570 & 0.0380 & 0.0000 & 100.0000 & 0.2320 & 99.7680 \\
\hline Top.100.Uni.Country & focus & -0.0340 & 0.0080 & 90.0000 & 0.0000 & 99.1120 & 0.8880 \\
\hline Top.500.Uni.City & focus & 0.0800 & 0.0380 & 0.0000 & 35.0000 & 8.5510 & 91.4490 \\
\hline Top.500.Uni.Country & focus & 0.0320 & 0.0050 & 0.0000 & 100.0000 & 0.0080 & 99.9920 \\
\hline English.Language & focus & 0.7820 & 0.2290 & 5.0000 & 85.0000 & 6.2790 & 93.7210 \\
\hline \multicolumn{8}{|l|}{ Infrastructure } \\
\hline LN.Metro.Stations & focus & -0.0080 & 0.0220 & 21.7390 & 21.7390 & 48.2610 & 51.7390 \\
\hline \multicolumn{8}{|l|}{ Non-financial sector development } \\
\hline Foreign.Sales.Pct & free & 0.0300 & 0.0110 & 0.0000 & 77.1650 & 3.1310 & 96.8690 \\
\hline HQ.10bn.Count.City & focus & 0.0010 & 0.0020 & 13.6360 & 18.1820 & 49.4800 & 50.5200 \\
\hline HQ.10bn. Count.Cntry & focus & -0.0050 & 0.0010 & 90.9090 & 0.0000 & 96.2590 & 3.7410 \\
\hline LN.Seaport.TEU & focus & -0.0960 & 0.0110 & 100.0000 & 0.0000 & 100.0000 & 0.0000 \\
\hline \multicolumn{8}{|l|}{ Financial sector development } \\
\hline Advisor.HF.City & free & 3.3220 & 0.7710 & 0.0000 & 85.8270 & 2.2690 & 97.7310 \\
\hline Advisor.HF.SQ.City & free & -4.8120 & 1.0480 & 90.5510 & 0.0000 & 98.9400 & 1.0600 \\
\hline Top.Dom.Fin.Centre & free & 0.8660 & 0.1420 & 0.0000 & 98.8190 & 0.3700 & 99.6300 \\
\hline Stock. Exchange & free & 1.8480 & 0.1340 & 1.1810 & 95.2760 & 2.9890 & 97.0110 \\
\hline Stock.Market.Return & focus & 0.3390 & 0.2710 & 0.0000 & 30.4350 & 17.0040 & 82.9960 \\
\hline Gov.Gross.Debt.Pct.GDP & focus & -0.0010 & 0.0020 & 21.7390 & 39.1300 & 31.9730 & 68.0270 \\
\hline \multicolumn{8}{|l|}{ Taxes } \\
\hline Dividends.Tax & focus & -0.0150 & 0.0080 & 60.0000 & 5.0000 & 79.3830 & 20.6170 \\
\hline Interest.Tax & focus & -0.0070 & 0.0100 & 25.0000 & 5.0000 & 64.1860 & 35.8140 \\
\hline Corp.Tax.Rate & focus & 0.0270 & 0.0200 & 5.0000 & 35.0000 & 23.2830 & 76.7170 \\
\hline Pers.Inc.Tax.Soc.Sec & focus & -0.0420 & 0.0070 & 100.0000 & 0.0000 & 99.9280 & 0.0720 \\
\hline \multicolumn{8}{|l|}{ Macroeconomic conditions } \\
\hline Inflation.Avg.Prices & free & -0.0250 & 0.0230 & 38.1890 & 7.0870 & 71.7930 & 28.2070 \\
\hline Real.Int.Rate & free & -0.0030 & 0.0060 & 20.0790 & 21.6540 & 47.9920 & 52.0080 \\
\hline \multicolumn{8}{|l|}{ Other conditions } \\
\hline Spat.Adj.Live.Top.25 & focus & 1.2940 & 0.2090 & 0.0000 & 91.3040 & 0.4510 & 99.5490 \\
\hline GMT & focus & 2.0880 & 0.6690 & 0.0000 & 78.2610 & 1.5050 & 98.4950 \\
\hline \multicolumn{8}{|l|}{ Correlated random effects terms } \\
\hline (M) Foreign.Sales.Pct & free & -0.0020 & 0.0140 & 19.6850 & 17.7170 & 45.6100 & 54.3900 \\
\hline (M) Advisor.HF.City & free & 6.8010 & 0.4880 & 0.0000 & 100.0000 & 0.0010 & 99.9990 \\
\hline (M) Cost.Enfr.Contract.Pct.Claim.L1 & free & 0.1260 & 0.0400 & 0.3940 & 72.0470 & 7.3340 & 92.6660 \\
\hline (M) Rule.of.Law.Rank.L1 & free & -0.0710 & 0.0160 & 92.1260 & 0.0000 & 98.6450 & 1.3550 \\
\hline (M) LN.Population.City & free & -6.7610 & 0.8700 & 99.6060 & 0.0000 & 99.8110 & 0.1890 \\
\hline
\end{tabular}

Free variables have been included in every model estimated as part of the EBA routine. Focus variables have been included in groups of two in each model. Exhaustive set of 254 combinations of CREQR models has been estimated. Variables starting with (M) are CRE terms (average of those variables for each cross-section) constructed to control for the correlation between some of the regressors and the error term, due to their relationship with the time constant unobserved heterogeneity. Time period dummy variables (Y2002-Y2014) have been included in every model in addition to a common intercept. 
Table A5. Stock market development

\begin{tabular}{|c|c|c|c|c|c|c|}
\hline \multirow{3}{*}{ Percentile } & \multicolumn{6}{|c|}{ Dependent variable - LN.Xborder.Fees } \\
\hline & \multicolumn{2}{|l|}{ 99.9th } & \multicolumn{2}{|l|}{ 99th } & \multicolumn{2}{|l|}{ 95th } \\
\hline & Coefficient & t-stat. & Coefficient & t-stat. & Coefficient & t-stat. \\
\hline \multicolumn{7}{|l|}{ City level explanatory variables } \\
\hline Advisor.HF.City & $4.5759 * *$ & $(2.4172)$ & $4.4544 *$ & $(1.9480)$ & $6.1563 * *$ & $(2.3470)$ \\
\hline Advisor.HF.City.SQ & $-4.5928 * * *$ & $(-2.8046)$ & $-4.6093 *$ & $(-1.8163)$ & $-8.3074 * *$ & $(-2.3319)$ \\
\hline Stock.Exchange & $1.9555 * * *$ & $(4.3703)$ & $2.1191 * * *$ & $(2.8481)$ & 1.7968 & $(1.3724)$ \\
\hline Top.Dom.Fin.Centre & $1.1489 * *$ & $(2.4900)$ & $1.1380 *$ & $(1.7220)$ & $1.9341 *$ & $(1.9314)$ \\
\hline LN.Population.City & $4.8868 * *$ & $(2.0577)$ & 5.7133 & $(1.5401)$ & 4.0491 & $(0.7047)$ \\
\hline \multicolumn{7}{|l|}{ Country level explanatory variables } \\
\hline Stocks.Tot.Val.Pct.GDP & 0.2074 & $(0.9726)$ & 0.2154 & $(0.5255)$ & -0.0412 & $(-0.0793)$ \\
\hline Cost.Enfr.Contract.Pct.Claim.L1 & $-0.3063 * * *$ & $(-3.0905)$ & $-0.3274 * *$ & $(-2.1350)$ & -0.1832 & $(-0.7228)$ \\
\hline Rule.of.Law.L1 & $0.1002 * * *$ & $(5.8052)$ & $0.1032 * * *$ & (3.2072) & $0.1337 * *$ & (2.1826) \\
\hline EU.Member & 0.9522 & $(0.6715)$ & 1.1631 & $(0.6588)$ & -0.5810 & $(-0.3048)$ \\
\hline Foreign.Sales.Pct & $0.0397 * *$ & $(2.2887)$ & 0.0308 & $(1.1650)$ & 0.0334 & $(0.9062)$ \\
\hline Real.Int. Rate & $-0.0909 * * *$ & $(-3.8896)$ & $-0.0965 * * *$ & $(-2.5826)$ & -0.0664 & $(-1.1071)$ \\
\hline Inflation.Avg.Prices & -0.0605 & $(-1.4891)$ & -0.0615 & $(-0.7865)$ & 0.0044 & $(0.0348)$ \\
\hline Redundancy.Costs. Weeks & $-0.1391 * * *$ & $(-8.4834)$ & $-0.1436 * * *$ & $(-5.1093)$ & $-0.1631 * * *$ & $(-3.2277)$ \\
\hline Top.500.Uni.Country & $0.0406 * *$ & $(2.1754)$ & 0.0396 & $(1.5044)$ & 0.0293 & $(0.7174)$ \\
\hline \multicolumn{7}{|l|}{ Correlated random effects terms } \\
\hline (M) Advisor.HF.City & $4.5406 * * *$ & $(3.4011)$ & $4.4816 * * *$ & $(2.5831)$ & $8.4076 * * *$ & $(2.9304)$ \\
\hline (M) LN.Population.City & -3.6796 & $(-1.6315)$ & -4.4413 & $(-1.2230)$ & -2.6350 & $(-0.4674)$ \\
\hline (M) Cost.Enfr.Contract.Pct.Claim.L1 & $0.3080 * * *$ & $(3.1212)$ & $0.3308 * *$ & $(2.1340)$ & 0.1842 & $(0.7228)$ \\
\hline (M) Rule.of.Law.L1 & $-0.0790 * * *$ & $(-3.3127)$ & $-0.0854 * *$ & $(-2.0408)$ & -0.1162 & $(-1.6343)$ \\
\hline (M) Stocks.Tot.Val.Pct.GDP & -0.0100 & $(-0.0307)$ & 0.0278 & $(0.0487)$ & 0.1578 & (0.2206) \\
\hline (M) Foreign.Sales.Pct & -0.0264 & $(-0.9840)$ & -0.0123 & $(-0.3528)$ & 0.0210 & $(0.3794)$ \\
\hline (M) EU.Member & -0.7441 & $(-0.5078)$ & -0.9818 & $(-0.4745)$ & 0.5340 & $(0.2293)$ \\
\hline (M) Real.Int.Rate & $0.0747 * * *$ & $(3.7943)$ & $0.0835 * *$ & $(2.2895)$ & 0.0547 & $(0.5283)$ \\
\hline Time period dummy variables & yes & & yes & & yes & \\
\hline Cross-sections (time periods) & 150 & $(13)$ & 150 & $(13)$ & 150 & $(13)$ \\
\hline
\end{tabular}

*** Significant at $1 \%$ level, ** at $5 \%$ level, * at $10 \%$ level

Data used for estimation of this model is limited to 2000 - 2012 time periods due to availability of data on the Stocks.Tot.Val.Pct.GDP variable. In all other respects this model mimics that presented in table 5 with the sole addition of Stocks.Tot.Val.Pct.GDP and the corresponding CRE term. 
Table A6. Asset managers

\begin{tabular}{|c|c|c|c|c|c|c|}
\hline \multirow{3}{*}{ Percentile } & \multicolumn{6}{|c|}{ Dependent variable - LN.Xborder.Fees } \\
\hline & \multicolumn{2}{|c|}{ 99.9th } & \multicolumn{2}{|l|}{ 99th } & \multicolumn{2}{|c|}{ 95th } \\
\hline & Coefficient & t-stat. & Coefficient & t-stat. & Coefficient & t-stat. \\
\hline \multicolumn{7}{|l|}{ City level explanatory variables } \\
\hline LN.Assets.U.Mng.City & $0.0824 * * *$ & (3.4089) & $0.0824 * *$ & $(2.5154)$ & 0.1063 & $(1.2082)$ \\
\hline Advisor.HF.City & $10.0057 * * *$ & (3.3935) & $10.0057 * *$ & $(2.2403)$ & $13.1003 * *$ & $(2.3457)$ \\
\hline Advisor.HF.City.SQ & $-14.0606 * * *$ & $(-3.3982)$ & $-14.0606 * *$ & $(-2.2773)$ & $-18.6864 * *$ & $(-2.1999)$ \\
\hline Stock.Exchange & $1.7399 *$ & $(1.9433)$ & $1.7399 *$ & $(1.7482)$ & 0.6864 & $(0.4974)$ \\
\hline Top.Dom.Fin.Centre & $1.1579 * *$ & $(1.9746)$ & 1.1579 & $(1.4993)$ & 1.9351 & $(1.5546)$ \\
\hline LN.Population.City & 1.1622 & $(0.2947)$ & 1.1622 & $(0.1905)$ & 2.7641 & $(0.2991)$ \\
\hline \multicolumn{7}{|l|}{ Country level explanatory variables } \\
\hline LN.Assets.U.Mng.Country & 0.0053 & $(0.1638)$ & 0.0053 & $(0.1058)$ & -0.0547 & $(-0.5035)$ \\
\hline Cost.Enfr.Contract.Pct.Claim.L1 & -0.0533 & $(-0.3357)$ & -0.0533 & $(-0.2830)$ & -0.1842 & $(-0.7129)$ \\
\hline Rule.of.Law.L1 & $0.3089 * * *$ & (5.1777) & $0.3089 * * *$ & (3.2967) & $0.3319 * *$ & (2.3888) \\
\hline EU.Member & $3.4099 * *$ & $(2.0204)$ & $3.4497 * *$ & $(2.1974)$ & 3.8554 & (1.1976) \\
\hline Foreign.Sales.Pct & $0.0962 * * *$ & $(2.8105)$ & $0.0962 * *$ & $(2.3861)$ & $0.0839 *$ & $(1.8502)$ \\
\hline Real.Int.Rate & $-0.1386 * * *$ & $(-3.5184)$ & $-0.1386 * *$ & $(-2.3651)$ & $-0.1760 * *$ & $(-1.9775)$ \\
\hline Inflation.Avg.Prices & 0.1996 & $(1.6314)$ & 0.1996 & $(1.3139)$ & 0.1904 & $(0.8450)$ \\
\hline Redundancy.Costs.Weeks & $-0.0771 * *$ & $(-2.0461)$ & -0.0771 & $(-1.3330)$ & -0.1411 & $(-1.6072)$ \\
\hline Top.500.Uni.Country & -0.0156 & $(-0.5381)$ & -0.0156 & $(-0.3604)$ & -0.0207 & $(-0.3037)$ \\
\hline \multicolumn{7}{|l|}{ Correlated random effects terms } \\
\hline (M) Advisor.HF.City & 0.9889 & $(0.4322)$ & 0.9889 & $(0.3334)$ & 2.2804 & $(0.6055)$ \\
\hline (M) LN.Population.City & 0.0123 & $(0.0033)$ & 0.0123 & $(0.0020)$ & -1.4267 & $(-0.1545)$ \\
\hline (M) Cost.Enfr.Contract.Pct.Claim.L1 & 0.0484 & $(0.3013)$ & 0.0484 & $(0.2531)$ & 0.1781 & $(0.6767)$ \\
\hline (M) Rule.of.Law.L1 & $-0.2905 * * *$ & $(-4.9039)$ & $-0.2905 * * *$ & $(-3.2218)$ & $-0.3260 * *$ & $(-2.3522)$ \\
\hline (M) EU.Member & $-3.3833 * *$ & $(-2.1215)$ & $-3.4230 *$ & $(-1.8833)$ & -3.2137 & $(-0.8313)$ \\
\hline (M) Foreign.Sales.Pct & -0.0377 & $(-0.7225)$ & -0.0377 & $(-0.6358)$ & -0.0118 & $(-0.1460)$ \\
\hline (M) Real.Int.Rate & $0.0600 *$ & $(1.6945)$ & 0.0600 & (0.9269) & 0.1104 & (0.9089) \\
\hline Time period dummy variables & yes & & yes & & yes & \\
\hline Cross-sections (time periods) & 150 & (6) & 150 & (6) & 150 & $=(6)$ \\
\hline
\end{tabular}

*** Significant at $1 \%$ level, ** at $5 \%$ level, * at $10 \%$ level

The regression output presented here is based on a subsample of data for years 2006, 2007, 2009, 2010,2011 and 2012 due to data availability constraints on LN.Assets.U.Mng.City and LN.Assets.U.Mng.Country, both of which are based on propriatory data obtained from Towers Watson, covering top 500 asset managers worldwide over the respective time periods. 
Table A7. Asset managers - CRE correction

\begin{tabular}{|c|c|c|c|c|c|c|}
\hline \multirow{3}{*}{ Percentile } & \multicolumn{6}{|c|}{ Dependent variable - LN.Xborder.Fees } \\
\hline & \multicolumn{2}{|c|}{ 99.9th } & \multicolumn{2}{|l|}{ 99th } & \multicolumn{2}{|l|}{ 95th } \\
\hline & Coefficient & t-stat. & Coefficient & t-stat. & Coefficient & t-stat. \\
\hline \multicolumn{7}{|l|}{ City level explanatory variables } \\
\hline LN.Assets.U.Mng.City & 0.0431 & $(0.3531)$ & 0.0431 & $(0.3719)$ & 0.0345 & $(0.1701)$ \\
\hline Advisor.HF.City & $9.7842 * * *$ & (3.1404) & $9.7842 * *$ & $(2.2018)$ & $12.2819 * *$ & $(2.2943)$ \\
\hline Advisor.HF.City.SQ & $-13.7613 * * *$ & $(-3.1494)$ & $-13.7613 * *$ & $(-2.2303)$ & $-17.4470 * *$ & $(-2.2530)$ \\
\hline Stock.Exchange & $1.8510 * *$ & $(2.0083)$ & $1.8510 *$ & $(1.7740)$ & 0.7233 & $(0.5001)$ \\
\hline Top.Dom.Fin.Centre & $1.2844 * *$ & $(2.2066)$ & $1.2844 *$ & $(1.7801)$ & $2.0342 *$ & $(1.7506)$ \\
\hline LN.Population.City & 0.7140 & $(0.1773)$ & 0.7140 & $(0.1224)$ & 2.9356 & $(0.3368)$ \\
\hline \multicolumn{7}{|l|}{ Country level explanatory variables } \\
\hline LN.Assets.U.Mng.Country & 0.0088 & $(0.2597)$ & 0.0088 & $(0.1616)$ & -0.0754 & $(-0.6640)$ \\
\hline Cost.Enfr.Contract.Pct.Claim.L1 & -0.0783 & $(-0.4529)$ & -0.0783 & $(-0.4130)$ & -0.2622 & $(-1.0168)$ \\
\hline Rule.of.Law.L1 & $0.3121 * * *$ & $(5.0875)$ & $0.3121 * * *$ & $(3.1654)$ & $0.2994 * *$ & $(2.2672)$ \\
\hline Foreign.Sales.Pct & $0.0949 * * *$ & $(2.7417)$ & $0.0949 * *$ & $(2.3285)$ & 0.0669 & $(1.4522)$ \\
\hline EU.Member & $3.7035 * *$ & $(2.3449)$ & $3.7491 * *$ & (2.3899) & $3.9082 *$ & $(1.7721)$ \\
\hline Real.Int.Rate & $-0.1488 * * *$ & $(-3.4220)$ & $-0.1488 * * *$ & $(-2.5930)$ & $-0.2021 * *$ & $(-2.2135)$ \\
\hline Inflation.Avg.Prices & $0.2179 *$ & $(1.7353)$ & 0.2179 & $(1.3738)$ & 0.1789 & $(0.7276)$ \\
\hline Redundancy.Costs. Weeks & $-0.0718^{*}$ & $(-1.8960)$ & -0.0718 & $(-1.2203)$ & $-0.1567 *$ & $(-1.8136)$ \\
\hline Top.500.Uni.Country & -0.0106 & $(-0.3514)$ & -0.0106 & $(-0.2413)$ & 0.0004 & $(0.0056)$ \\
\hline \multicolumn{7}{|l|}{ Correlated random effects terms } \\
\hline (M) LN.Assets.U.Mng.City & 0.0378 & $(0.3186)$ & 0.0378 & $(0.3194)$ & 0.0750 & $(0.2835)$ \\
\hline (M) Advisor.HF.City & 1.1767 & $(0.4626)$ & 1.1767 & $(0.3756)$ & 2.0501 & $(0.6017)$ \\
\hline (M) LN.Population.City & 0.3453 & $(0.0896)$ & 0.3453 & $(0.0592)$ & -1.6867 & $(-0.1918)$ \\
\hline (M) Cost.Enfr.Contract.Pct.Claim.L1 & 0.0750 & $(0.4281)$ & 0.0750 & $(0.3916)$ & 0.2613 & $(0.9900)$ \\
\hline (M) Rule.of.Law.L1 & $-0.2907 * * *$ & $(-4.7568)$ & $-0.2907 * * *$ & $(-3.0558)$ & $-0.2919 * *$ & $(-2.1929)$ \\
\hline (M) EU.Member & $-3.6641 * *$ & $(-2.5153)$ & $-3.7098 * *$ & $(-2.0359)$ & -3.7364 & $(-1.2129)$ \\
\hline (M) Foreign.Sales.Pct & -0.0457 & $(-0.8331)$ & -0.0457 & $(-0.7103)$ & -0.0003 & $(-0.0033)$ \\
\hline (M) Real.Int.Rate & 0.0659 & $(1.6101)$ & 0.0659 & $(1.0192)$ & 0.1406 & $(1.1137)$ \\
\hline Time period dummy variables & yes & & yes & & yes & \\
\hline Cross-sections (time periods) & 150 & $(6)$ & 150 & $(6)$ & 150 & (6) \\
\hline
\end{tabular}

*** Significant at $1 \%$ level, ** at $5 \%$ level, * at $10 \%$ level

The regression output presented here is based on a subsample of data for years 2006, 2007, 2009, 2010, 2011 and 2012 due to data availability constraints on LN.Assets.U.Mng.City and LN.Assets.U.Mng.Country, both of which are based on propriatory data obtained from Towers Watson, covering top 500 asset managers worldwide over the respective time periods. (M) LN.Assets.U.Mng.City is a correlated random effects (CRE) term constructed by averaging LN.Assets.U.Mng.City for each cross-section in order to correct for potential bias linked to time constant unobserved heterogeneity. 